\title{
Trends and drivers of ozone human health and vegetation impact metrics from UK EMEP supersite measurements (1990-2013)
}

\author{
C. S. Malley ${ }^{1,2}$, M. R. Heal ${ }^{1}$, G. Mills ${ }^{3}$, and C. F. Braban ${ }^{2}$ \\ ${ }^{1}$ School of Chemistry, University of Edinburgh, Edinburgh, UK \\ ${ }^{2}$ NERC Centre for Ecology \& Hydrology, Penicuik, UK \\ ${ }^{3}$ NERC Centre for Ecology \& Hydrology, Environment Centre Wales, Bangor, UK \\ Correspondence to: C. S. Malley (c.malley@ sms.ed.ac.uk)
}

Received: 5 November 2014 - Published in Atmos. Chem. Phys. Discuss.: 20 January 2015

Revised: 18 March 2015 - Accepted: 26 March 2015 - Published: 16 April 2015

\begin{abstract}
Analyses have been undertaken of the spatial and temporal trends and drivers of the distributions of groundlevel $\mathrm{O}_{3}$ concentrations associated with potential impacts on human health and vegetation using measurements at the two UK European Monitoring and Evaluation Program (EMEP) supersites of Harwell and Auchencorth. These two sites provide representation of rural $\mathrm{O}_{3}$ over the wider geographic areas of south-east England and northern UK respectively. The $\mathrm{O}_{3}$ exposures associated with health and vegetation impacts were quantified respectively by the SOMO10 and SOMO35 metrics and by the flux-based PODY metrics for wheat, potato, beech and Scots pine. Statistical analyses of measured $\mathrm{O}_{3}$ and $\mathrm{NO}_{x}$ concentrations were supplemented by analyses of meteorological data and $\mathrm{NO}_{x}$ emissions along air-mass back trajectories.

The findings highlight the differing responses of impact metrics to the decreasing contribution of regional $\mathrm{O}_{3}$ episodes in determining $\mathrm{O}_{3}$ concentrations at Harwell between 1990 and 2013, associated with European $\mathrm{NO}_{x}$ emission reductions. An improvement in human health-relevant $\mathrm{O}_{3}$ exposure observed when calculated by SOMO35, which decreased significantly, was not observed when quantified by SOMO10. The decrease in SOMO35 is driven by decreases in regionally produced $\mathrm{O}_{3}$ which makes a larger contribution to SOMO35 than to SOMO10. For the $\mathrm{O}_{3}$ vegetation impacts at Harwell, no significant trend was observed for the $\mathrm{POD}_{Y}$ metrics of the four species, in contrast to the decreasing trend in vegetation-relevant $\mathrm{O}_{3}$ exposure perceived when calculated using the crop AOT40 metric. The decreases in regional $\mathrm{O}_{3}$ production have not decreased $\mathrm{POD}_{\mathrm{Y}}$ as climatic
\end{abstract}

and plant conditions reduced stomatal conductance and uptake of $\mathrm{O}_{3}$ during regional $\mathrm{O}_{3}$ production.

Ozone concentrations at Auchencorth (2007-2013) were more influenced by hemispheric background concentrations than at Harwell. For health-related $\mathrm{O}_{3}$ exposures this resulted in lower SOMO35 but similar SOMO10 compared with Har-

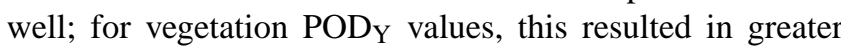
impacts at Auchencorth for vegetation types with lower exceedance ("Y") thresholds and longer growing seasons (i.e. beech and Scots pine). Additionally, during periods influenced by regional $\mathrm{O}_{3}$ production, a greater prevalence of plant conditions which enhance $\mathrm{O}_{3}$ uptake (such as higher soil water potential) at Auchencorth compared to Harwell resulted in exacerbation of vegetation impacts at Auchencorth, despite being further from $\mathrm{O}_{3}$ precursor emission sources.

These analyses indicate that quantifications of future improvement in health-relevant $\mathrm{O}_{3}$ exposure achievable from pan-European $\mathrm{O}_{3}$ mitigation strategies are highly dependent on the choice of $\mathrm{O}_{3}$ concentration cut-off threshold, and reduction in potential health impact associated with more modest $\mathrm{O}_{3}$ concentrations requires reductions in $\mathrm{O}_{3}$ precursors on a larger (hemispheric) spatial scale. Additionally, while further reduction in regional $\mathrm{O}_{3}$ is more likely to decrease $\mathrm{O}_{3}$ vegetation impacts within the spatial domain of Auchencorth compared to Harwell, larger reductions in vegetation impact could be achieved across the UK from reduction of hemispheric background $\mathrm{O}_{3}$ concentrations. 


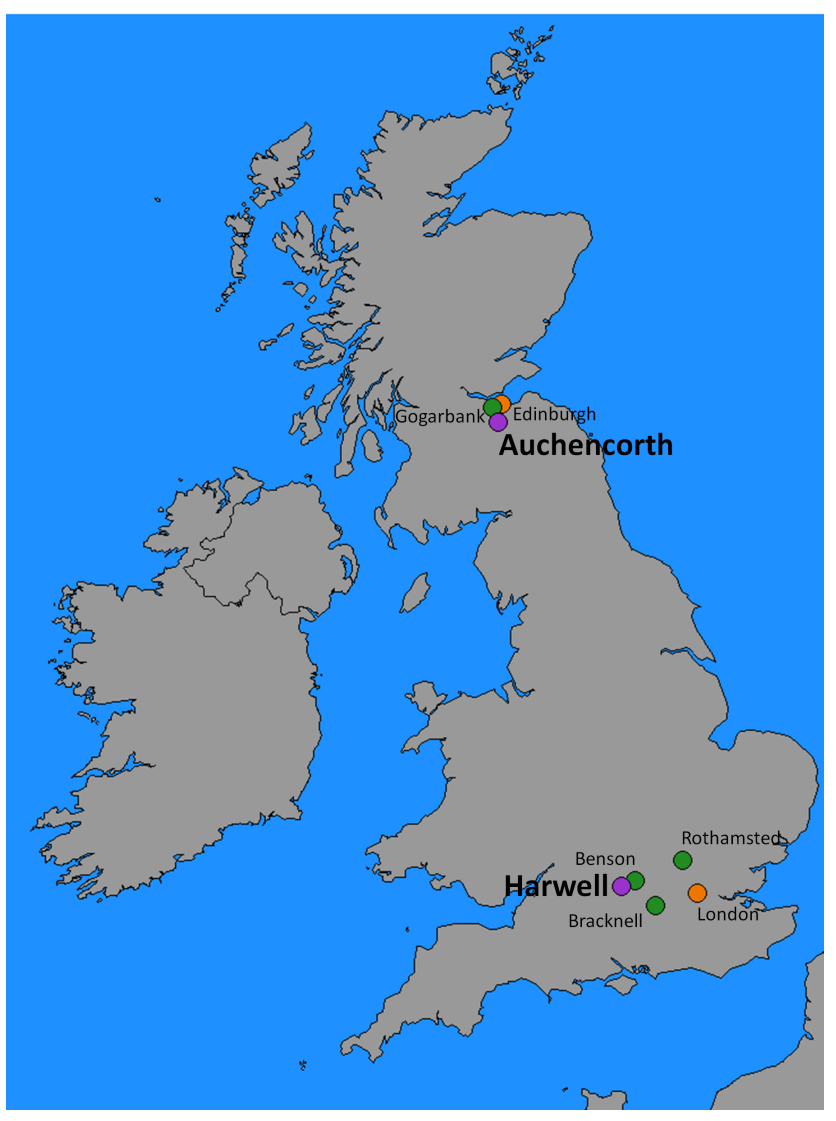

Figure 1. Map of the United Kingdom and Ireland showing the location of the two UK EMEP supersites (purple circles) at Auchencorth and Harwell, as well as the location of the UK Met Office stations from which meteorological data were used (green circles).

\section{Introduction}

As part of the European Monitoring and Evaluation Program (EMEP) monitoring network, the UK operates two level II "supersites" at Harwell (80 km west of London, Fig. 1) and Auchencorth (17 km south of Edinburgh, Fig. 1) (Tørseth et al., 2012). The utility of the supersite concept as part of a strategy to address air quality research issues through concurrent measurements of a suite of atmospheric constituents has recently been reinforced (Kuhlbusch et al., 2014). The distinct impacts of one of the constituents measured at Harwell and Auchencorth, ground-level ozone $\left(\mathrm{O}_{3}\right)$, on human health and vegetation have been widely studied (REVIHAAP, 2013; RoTAP, 2012), but changes in the recommended metrics by which $\mathrm{O}_{3}$ exposure relevant to these impacts is quantified (see below) necessitates new analyses of supersite measurement data.

The analyses in this study are based on the chemical climatology concept introduced by chemist Robert Angus Smith in "Air and rain: The beginnings of a chemical climatology" (Angus Smith, 1872). A chemical climatology approach comprises three elements (Malley et al., 2014a): (i) an "impact" of the atmospheric composition, often characterised through a metric; (ii) the "state" of relevant atmospheric composition variation (temporal, spatial and covariance) producing instances of the impact; and (iii) the "drivers" of this state, which could include meteorology, source proximity and emission profiles. A chemical climate has temporal boundaries (time period) and spatial boundaries (geographical extent); where there is identification of a significant change in the impact resulting from significant change to the drivers and state, these may be classified as different phases of the chemical climate.

In this study the six steps in the construction of a chemical climate described in Fig. 2 and outlined in Malley et al. (2014a) were applied to characterise the exposure of ground-level $\mathrm{O}_{3}$ concentrations measured at Harwell and Auchencorth relevant to human health and four vegetation types. The $\mathrm{O}_{3}$ measured at these sites has been shown to be representative of rural $\mathrm{O}_{3}$ concentrations in the larger geographical areas of south-east England and northern UK respectively (Malley et al., 2014b).

Ozone exposure relevant to health impacts is quantified using the SOMO10 and SOMO35 metrics, which are the annual sums of daily maximum running $8 \mathrm{~h}$ average $\mathrm{O}_{3}$ concentrations above 10 and $35 \mathrm{ppb}$ thresholds respectively. These metrics are in line with the recent World Health Organisation "Review of evidence on health aspects of air pollution" (REVIHAAP, 2013) report which recommends quantifying acute $\mathrm{O}_{3}$ health impacts using both these measures of daily $\mathrm{O}_{3}$ concentration and across the full year. In earlier syntheses of human health effects of $\mathrm{O}_{3}$, importance was attached to the peak $\mathrm{O}_{3}$ concentrations (WHO, 2006). The recent REVIHAAP synthesis shows important $\mathrm{O}_{3}$ effects on human health down to very small concentrations and a suggestion that there is no specific threshold for effects. The inclusion of SOMO10 reflects this recent synthesis. To quantify vegetation impacts of $\mathrm{O}_{3}$, the species-specific metric of phytotoxic $\mathrm{O}_{3}$ dose above a threshold flux $\mathrm{Y}\left(\mathrm{POD}_{\mathrm{Y}}\right)$ is used (LRTAP Convention, 2010). This parameter represents the modelled accumulated stomatal uptake of $\mathrm{O}_{3}$ over a fixed time period based on hourly variations in climate (temperature $(T)$, vapour pressure deficit (VPD), photosynthetically active radiation (PAR)), soil moisture (soil water potential (SWP) or plant available water (PAW)), $\mathrm{O}_{3}$ and plant phenology (Emberson et al., 2000). Stomatal flux metrics are increasingly used to assess $\mathrm{O}_{3}$ vegetation impacts, as they more accurately reflect the spatial pattern of $\mathrm{O}_{3}$ damage across $\mathrm{Eu}-$ rope than concentration-based metrics such as AOT40 (Mills et al., 2011b; RoTAP, 2012). Statistical analyses of $\mathrm{O}_{3}$ and $\mathrm{NO}_{x}$ variation provide characterisation of the "state" of atmospheric composition at the two sites for the different impacts, while analysis of meteorology, air-mass history and $\mathrm{NO}_{x}$ emissions provide insight into the relevant "drivers" of the chemical climates.

The focus of this study is to characterise the variation in $\mathrm{O}_{3}$ impacts, temporally at Harwell and spatially between Har- 
well and Auchencorth, and the contributions of regional and hemispheric $\mathrm{O}_{3}$-modifying processes in determining each impact. Hemispheric background $\mathrm{O}_{3}$ concentrations are defined here as $\mathrm{O}_{3}$ formed from anthropogenic and natural precursor emissions outside of Europe (Derwent et al., 2013). Superimposed on this, regional net $\mathrm{O}_{3}$ production or loss derives from the balance of processes such as emissions, deposition and meteorological conditions occurring on a regional scale. Photochemical reactions between $\mathrm{NO}_{x}$ and volatile organic compounds (VOCs) emitted in Europe produce $\mathrm{O}_{3}$ regionally, but high $\mathrm{NO}_{x}$ environments (regionally and locally) limit $\mathrm{O}_{3}$ formation (Jenkin, 2008; Munir et al., 2013). Spatial and temporal variation of these processes in the UK context have been discussed previously (AQEG, 2009). Studies have also quantified both human health (EMEP, 2014; Stedman and Kent, 2008; Gauss et al., 2014; Guerreiro et al., 2014) and vegetation $\mathrm{O}_{3}$ impacts (Mills et al., 2011a; RoTAP, 2012) within the spatial domain of each supersite. However, consideration of both impacts at each site using a common chemical climatology approach links the impact studies with the analyses of temporal and spatial $\mathrm{O}_{3}$ variation and allows identification of differences and similarities in the drivers of each impact, which inform the development of co-beneficial $\mathrm{O}_{3}$ mitigation strategies.

An important aspect of this study is to also compare impacts quantified through the updated metrics with previously used metrics. For the health impact the contrast is between health-relevant exposure quantified by SOMO10 and SOMO35 and that quantified using the higher thresholds of the WHO guideline (50 ppb) and the EU target value (60 ppb) (Derwent et al., 2013; EEA, 2014b). For the vegetation impact the contrast is between the $\mathrm{POD}_{\mathrm{Y}}$ metric and the concentration-based crop AOT40 metric, the sum of hourly $\mathrm{O}_{3}$ concentrations above $40 \mathrm{ppb}$ during daylight hours during the growing season (Coyle et al., 2002; Klingberg et al., 2014; Jenkin, 2014). In addition, a comparison is made between $\mathrm{POD}_{\mathrm{Y}}$ calculated using on-site measured $\mathrm{O}_{3}$ and meteorological data (used in this study and previously in Karlsson et al., 2007) and analyses which have used gridded modelled $\mathrm{O}_{3}$ and meteorological data to calculate PODY (Emberson et al., 2007; Klingberg et al., 2011; Mills et al., 2011a, b; Simpson et al., 2007).

The ambition to integrate data (such as measured concentrations) with knowledge (such as the adverse impacts of $\mathrm{O}_{3}$ ) to advance both science and policy is currently an area of intense research interest (Schmale et al., 2014; Abbatt et al., 2014; Kuhlbusch et al., 2014). This current work, using the chemical climatology concept, presents a clear methodology for achieving this and shows a simple categorisation for summarising information which could be more widely adopted.

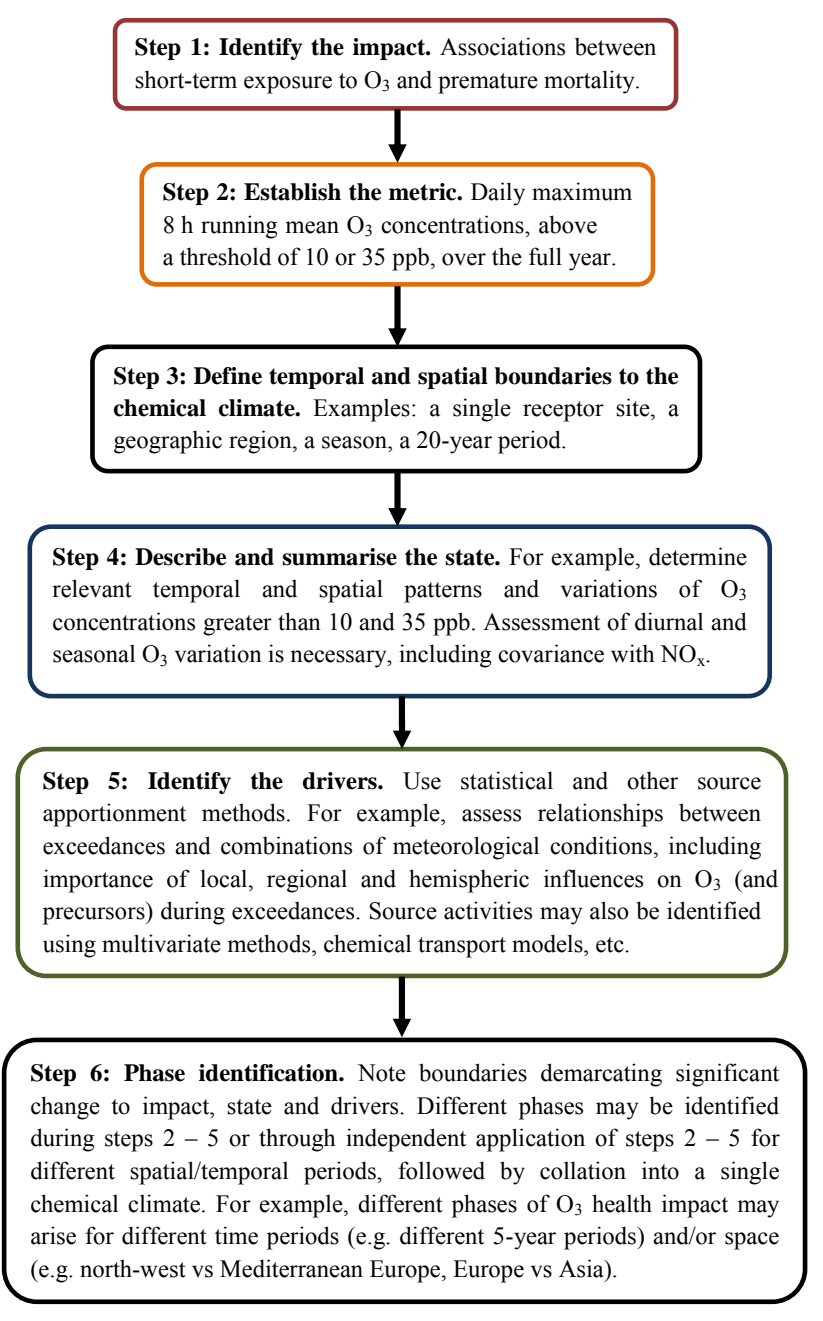

Figure 2. Practical steps for derivation of a chemical climate. The impact of premature mortality associated with short-term exposure to $\mathrm{O}_{3}$ is used as an example. Text in the chemical climate data sheets is coloured the same as the step which gave rise to the statistic. The details of application of these six steps to the focus of this study are described in Sect. 2.

\section{Methods}

A chemical climate is based on an identified impact (Fig. 2, Step 1), which is linked to atmospheric composition variation through a suitable metric (Step 2). For assessment of $\mathrm{O}_{3}$ acute health impact, REVIHAAP (2013) recommends the use of all-year metrics based on the value by which the daily maximum $8 \mathrm{~h}$ average $\mathrm{O}_{3}$ concentration exceeds either 10 or $35 \mathrm{ppb}$. The annual sum of the daily exceedances of these thresholds yields the SOMO10 and SOMO35 metrics respectively. The $\mathrm{POD}_{\mathrm{Y}}$ metric for the vegetation chemical climates was calculated using the $\mathrm{DO}_{3} \mathrm{SE}$ model version 3.0.5 (http://www.sei-international.org/do3se; Emberson et al., 2000). PODY values were calculated for two crops (wheat and potato) and two forest trees (beech and Scots pine), 
accumulated across their respective growing seasons. The length of the growing seasons and phenological limitation on stomatal conductance throughout the growing season were derived according to methods detailed in LRTAP Convention (2010). The growing seasons for wheat (late April-early August) and potato (late May-early September) were calculated by accumulated temperature and therefore varied interannually based on meteorological conditions. For beech, the growing season was calculated using a latitude model (19 April-20 October at Harwell, 26 April-10 October at Auchencorth). The Scots pine growing season was the full year.

The $\mathrm{DO}_{3} \mathrm{SE}$ model calculates the stomatal flux for each species using parameterisations which quantify the sensitivity of each species to modification of stomatal conductance due to the effects of phenology, $\mathrm{O}_{3}$, PAR, $T$, VPD and soil moisture (SWP for potato, beech and Scots pine and PAW for wheat; LRTAP Convention, 2010). For this study, the $\mathrm{DO}_{3} \mathrm{SE}$ model used hourly measured $\mathrm{O}_{3}$ concentrations at Harwell and Auchencorth as input, and the following hourly meteorological data from the Met Office stations closest to each monitoring site: wind speed, rainfall, vapour pressure deficit, temperature, global radiation and pressure (UK Meteorological Office, 2012). For Harwell, the station in Benson (SRC ID: 613 ) at a $13 \mathrm{~km}$ distance, provided all meteorological data except global radiation, which was obtained from Bracknell (SRC ID: 838, 1990-2002) and Rothamsted (SRC ID: 471, 2003-2013). For Auchencorth, all meteorological data were obtained from the station in Gogarbank (SRC ID: 19260) at a $14 \mathrm{~km}$ distance. All archived data from these stations undergo documented quality control procedures (http://badc.nerc.ac. uk/data/ukmo-midas/ukmo_guide.html). The $\mathrm{DO}_{3} \mathrm{SE}$ model calculated hourly $\mathrm{O}_{3}$ concentrations at the top of the canopy and stomatal conductance for each vegetation type (LRTAP Convention, 2010; Emberson et al., 2000). SWP and PAW were calculated in the $\mathrm{DO}_{3}$ SE model using the measured meteorological data based on the Penman-Monteith model of evapotranspiration (Büker et al., 2012). In addition to meteorological conditions, the evaporation of moisture from soil is dependent on the hydraulic properties of the soil texture. Statistics were therefore calculated for four different soil textures: sandy loam (soil texture classification $=$ coarse), silt loam (medium coarse), loam (medium) and clay loam (fine). The properties of these soil textures are detailed in Büker et al. (2012).

PODY was accumulated when this stomatal flux was above a plant-specific threshold flux set at $6 \mathrm{nmol} \mathrm{m}^{-2} \mathrm{~s}^{-1}$ for crops and $1 \mathrm{nmol} \mathrm{m}{ }^{-2} \mathrm{~s}^{-1}$ for forest trees. Response functions were

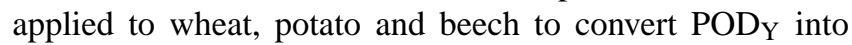
grain yield, tuber weight and whole-tree biomass reduction estimates respectively (Mills et al., 2011c). As the representative coniferous species in the "Atlantic central Europe" geographic zone (LRTAP Convention, 2010), Scots pine was included despite no published response function, with increasing $\mathrm{POD}_{\mathrm{Y}}$ assumed to indicate increasing poten- tial damage. In addition, the crop-specific AOT40 metric for May-July was calculated (Fuhrer et al., 1997) to allow for comparison with previous studies that used AOT40 to estimate the impact of $\mathrm{O}_{3}$ on crops (e.g. Derwent et al., 2013; Jenkin, 2014).

The spatial domain (Fig. 2, Step 3) in this analysis was the area of representativeness of each monitoring site. In the context of European $\mathrm{O}_{3}$ variation evaluated across all EMEP sites measuring $\mathrm{O}_{3}$, Harwell was shown to be representative of rural sites within $120 \mathrm{~km}$ of London, and Auchencorth was representative of rural locations in a larger domain including the rest of the UK (Malley et al., 2014b). The temporal domain investigated was 1990-2013 for Harwell $\left(\mathrm{NO}_{x}\right.$ data available from 1996) and 2007-2013 for Auchencorth. The $\mathrm{NO}_{x}$ and $\mathrm{O}_{3}$ measurements were co-located at Harwell, but the $\mathrm{NO}_{x}$ data for analyses at Auchencorth were obtained from Bush (UK-AIR ID: UKA00128), $8 \mathrm{~km}$ from Auchencorth. The suitability of Bush as a proxy site for Auchencorth has been outlined previously, and $\mathrm{O}_{3}$ variation was found to be similar at both sites (Malley et al., 2014b). The chemical data were downloaded from the UK-Air data repository (http://uk-air.defra.gov.uk) and the Automatic Urban and Rural Network (AURN) reports provide further details on these measurements (Eaton and Stacey, 2012).

A minimum data capture of $75 \%$ across the year for SOMO10/35 calculations, and across the relevant growing season for $\mathrm{POD}_{\mathrm{Y}}$ and AOT40 calculations, was imposed for inclusion in the summary statistics. This resulted only in the exclusion of statistics at Harwell for potato in 1995 and Scots pine in 1993. As data capture was generally very high, no adjustment of summary statistics for missing data was applied. At Harwell, average annual data capture for 19902013 was $94 \%$. The lowest annual data capture was $76 \%$ (1993). When the missing hourly $\mathrm{O}_{3}$ data were estimated through linear interpolation, 1993 SOMO35 and SOMO10 increased by no more than $2 \%$ compared to no interpolation. For the four vegetation types, the 1990-2013 average data capture during the respective growing seasons at Harwell was between 92 and $94 \%$. Sensitivity to missing $\mathrm{O}_{3}$ and meteorological data during the years of lowest data capture (above $75 \%$ ) for wheat $(1994,75 \%)$, potato $(1993,80 \%)$, beech $(1995,82 \%)$ and pine $(2007,81 \%)$ was also evaluated through linear interpolation. POD $_{Y}$ values were 19, 19 and $18 \%$ higher for wheat, beech and pine respectively, compared to no linear interpolation, and $6 \%$ lower for potato. These sensitivities illustrate an estimate of the greatest extent of impact metrics not included due to missing data. For the majority of years, biases will be much smaller, as data capture was substantially higher. As estimation of missing data introduces new sources of uncertainty, the impacts calculated using measured data only are considered here.

The state (Fig. 2, Step 4) of the human health chemical climates was characterised using the following statistics for the SOMO10 and SOMO35 metrics: the number of accumulation days (ADs), i.e. days on which the maximum $8 \mathrm{~h} \mathrm{O}_{3}$ 
concentration exceeded 10 or $35 \mathrm{ppb}$; percentage contribution per season to annual number of ADs; the percentage contribution per season to SOMO10/35; the average diurnal amplitudes in $\mathrm{O}_{3}, \mathrm{NO}$ and $\mathrm{NO}_{2}$ concentrations on $\mathrm{ADs}$ and non-accumulation days (NADs); and the contributions from 13 daily maximum $8 \mathrm{~h} \mathrm{O} 3$ concentration bins (between 10 and $>70 \mathrm{ppb}$ in $5 \mathrm{ppb}$ groups) to SOMO10/35. The state for the vegetation chemical climates was characterised by the following statistics for the $\mathrm{POD}_{\mathrm{Y}}$ metric for each vegetation type: the number of $\mathrm{POD}_{\mathrm{Y}}$ accumulation days; the percentage monthly contributions to PODY across the growing season; the contributions from 15 hourly $\mathrm{O}_{3}$ concentration bins (between 0 and $>70 \mathrm{ppb}$ in $5 \mathrm{ppb}$ groups) to $\mathrm{POD}_{\mathrm{Y}}$; and the average diurnal amplitudes of $\mathrm{O}_{3}, \mathrm{NO}$ and $\mathrm{NO}_{2}$ on $\mathrm{ADs}$ and NADs. For the AOT40 metric, the contributions from May, June and July were calculated as well as the average diurnal amplitudes in May, June and July of $\mathrm{O}_{3}, \mathrm{NO}$ and $\mathrm{NO}_{2}$.

Three potential drivers of the state (Step 5) were investigated. First, the effect of temperature was investigated using data from Benson (SRC ID: 613), $13 \mathrm{~km}$ from Harwell, and Gogarbank (SRC ID: 19260), $14 \mathrm{~km}$ from Auchencorth (UK Meteorological Office, 2012). The mean daily temperature on ADs and NADs for SOMO10/35 and PODY were compared. Monthly averaged temperatures during the AOT40 growing season were calculated. Second, the association of the state (Step 4) with air-mass history was investigated by grouping back trajectories based on the similarity of their pathway. The proportion of trajectories arriving from each group during SOMO10/35 and $\mathrm{POD}_{\mathrm{Y}}$ ADs and NADs, as well as over the AOT40 growing season, was then compared. Pre-calculated 4-day HYSPLIT air-mass back trajectories arriving at $3 \mathrm{~h}$ intervals (2920 trajectories per year) (Draxler and Rolph, 2013; Carslaw and Ropkins, 2013; R Core Development Team, 2008) were grouped using Ward's linkage hierarchical cluster analysis which has been shown through simulations to perform effectively (Mangiameli et al., 1996). The similarity between trajectories was quantified using the measure of their "angle" from the receptor (Eq. 1):

$d_{1,2}=\frac{1}{n} \sum_{i=1}^{n} \cos ^{-1}\left(0.5 \frac{A_{i}+B_{i}+C_{i}}{\sqrt{A_{i} B_{i}}}\right)$,

where

$A_{i}=\left(X_{1}(i)-X_{0}\right)^{2}+\left(Y_{1}(i)-Y_{0}\right)^{2}$,

$B_{i}=\left(X_{2}(i)-X_{0}\right)^{2}+\left(Y_{2}(i)-Y_{0}\right)^{2}$,

$C_{i}=\left(X_{2}(i)-X_{1}(i)\right)^{2}+\left(Y_{2}(i)-Y_{1}(i)\right)^{2}$,

$d_{1,2}$ is the variance between trajectory 1 and trajectory $2, X_{0}$ and $Y_{0}$ are the latitude and longitude coordinates of the origin of the back trajectory (i.e. the supersite) and $X_{1}, Y_{1}$ and $X_{2}, Y_{2}$ are the coordinates of back trajectories 1 and 2 respectively at a common time point $i$ along the trajectory. In Ward's method each object (back trajectory) initially constitutes its own cluster. At each step, the two clusters are merged that give the smallest increase in total within-cluster variance. This process is repeated until all trajectories are located in one cluster (Kaufman and Rousseeuw, 1990). The summary dendrogram was then "cut" to produce a set of four clusters in which the back trajectories were predominantly "westerly", "easterly", "northerly" and "southerly".

Third, the 2920 4-day back trajectories arriving each year were combined with reported gridded $\mathrm{NO}_{x}$ emissions to investigate the contribution of $\mathrm{NO}_{x}$ emissions as a chemical climate driver. Each $1 \mathrm{~h}$ time point along a trajectory was associated with the relevant $0.5^{\circ} \times 0.5^{\circ}$ grid square $\mathrm{NO}_{x}$ emissions reported by EMEP (Mareckova et al., 2013; Simpson et al., 2012). This grid encompasses the region $30.25^{\circ}-75.25^{\circ} \mathrm{N}$ and $29.75^{\circ} \mathrm{W}-60.25^{\circ} \mathrm{E}$. The associated annual $\mathrm{NO}_{x}$ gridded emissions were adjusted using month, day of week and hour of day time factors (Simpson et al., 2012) to obtain an estimate of the hourly $\mathrm{NO}_{x}$ emissions during the hour in which the trajectory passed over the grid cell. The 96hourly emission estimates for each trajectory were summed, and averaged across the eight trajectories arriving each day, producing a daily average trajectory $\mathrm{NO}_{x}$ emission estimate which was compared on SOMO10/35 and POD $\mathrm{ADs}$ and NADs. The monthly average trajectory $\mathrm{NO}_{x}$ emission estimate was calculated for the May-July AOT40 growing season.

The chemical climate statistics derived were compared between Harwell and Auchencorth for evidence of different spatial phases in the $\mathrm{O}_{3}$ impacts (Fig. 2, Step 6). Evidence for a different temporal phase in the $\mathrm{O}_{3}$ impact chemical climate at Harwell was investigated by Theil-Sen trend analysis of the 24-year time series of chemical climate statistics. This non-parametric test selects the median of all the slopes between pairs of points in a time series as the estimate of the trend and calculates statistical significance using bootstrap re-sampling (Carslaw and Ropkins, 2013). The 7-year data set from Auchencorth was of insufficient duration to evaluate significant changes in either the health or vegetation impacts.

The terminology spring, summer, autumn and winter refer to the 3-month periods Mar-Apr-May, Jun-Jul-Aug, SepOct-Nov and Dec-Jan-Feb respectively.

\section{Results and discussion}

The chemical climate statistics derived for the $\mathrm{O}_{3}$ human health and vegetation impacts at Harwell and Auchencorth are presented as data sheets in Tables S1-S12 in the Supplement. For Harwell, the statistics are averaged across six time periods (1990-1993, 1994-1997, 1998-2001, 20022005, 2006-2009, 2010-2013). These tables have a lot of statistics and exemplify a resource which could be replicated and collated for different impacts, locations and time periods to identify key linkages between chemical climates and aid in the development of more holistically considered mitigation strategies. The main features which support the key 
conclusions from the human health and vegetation $\mathrm{O}_{3}$ chemical climates at the UK supersites are presented in Figs. 3-14 and discussed in the following subsections.

\section{1 $\mathrm{O}_{3}$ human-health-impact chemical climates}

The detailed statistics describing the $\mathrm{O}_{3}$ human health chemical climates at Harwell and Auchencorth are presented in Tables $\mathrm{S} 1$ and $\mathrm{S} 2$ respectively. This section presents two analyses of the impact, state and drivers of the chemical climatology framework (Fig. 2, steps 1-5): specifically, changes in chemical climate phase (Fig. 2, Step 6) temporally at Harwell between 1990 and 2013 (Sect. 3.1.1) and spatially between Auchencorth and Harwell (Sect. 3.1.2).

\subsubsection{Long-term changes at Harwell}

When characterised by the SOMO35 metric, the $\mathrm{O}_{3}$ exposure associated with human health impact at Harwell decreased significantly between 1990 and 2013 (Fig. 3), with a median trend of $-2.2 \% \mathrm{y}^{-1}(p=0.001)$. The annual number of SOMO35 accumulation days did not vary significantly during this period, averaging $148 \pm 28$ days $^{-1}$. In contrast, when characterised by the SOMO10 metric, $\mathrm{O}_{3}$ exposure associated with human health impact at Harwell showed no statistically significant trend (1990-2013 mean $( \pm \mathrm{SD})=8329 \pm 802 \mathrm{ppbd}$ ) (Fig. 3). However, the annual number of SOMO10 ADs has increased significantly with a median trend of +1.7 days $^{-1}(p=0.01)$. In more recent years, the additional ADs occurred in winter, and SOMO10 was accumulated on almost every day of the year (Table S1).

The majority of SOMO35 accumulation at Harwell occurred in spring and summer (Fig. 4). Between 1990 and 2013 the spring contribution to SOMO35 increased significantly $\left(+1.1 \% \mathrm{y}^{-1}, p=0.01\right)$, whilst the summer contribution decreased significantly $\left(-1.2 \% \mathrm{y}^{-1}, p=0.01\right)$. The spring and summer contributions to SOMO35 values were considerably larger and showed larger interannual variation compared to those for SOMO10 (Fig. 4). Between 1990 and 2013 there was a significant decrease in contribution to SOMO10 during summer (trend $-0.4 \% \mathrm{y}^{-1}, p=0.01$ ) and a significant increase during winter $\left(+0.3 \% \mathrm{y}^{-1}, p=\right.$ 0.001 ).

Figure 5 shows the contributions from $135 \mathrm{ppb}$ daily maximum $8 \mathrm{~h} \mathrm{O} \mathrm{O}_{3}$ concentration bins to SOMO10 and SOMO35 at Harwell. The majority of SOMO10 was accumulated on days when the $\mathrm{O}_{3}$ concentration was between 25 and $45 \mathrm{ppb}$ (Fig. 5a). Contributions to SOMO10 from days with the highest concentrations $(60-70 \mathrm{ppb}$ and $>70 \mathrm{ppb})$ decreased significantly between 1990 and $2013\left(-0.2\right.$ and $-0.4 \% \mathrm{y}^{-1}$ respectively), while contributions from more moderate $\mathrm{O}_{3}$ concentrations (20-30 and 40-50 ppb) increased significantly $\left(+0.3\right.$ and $+0.2 \% \mathrm{y}^{-1}$ respectively). Ozone concentrations between 10 and $35 \mathrm{ppb}$, i.e. included in SOMO10 but not in SOMO35, contributed on average $40 \pm 8 \%$ across the

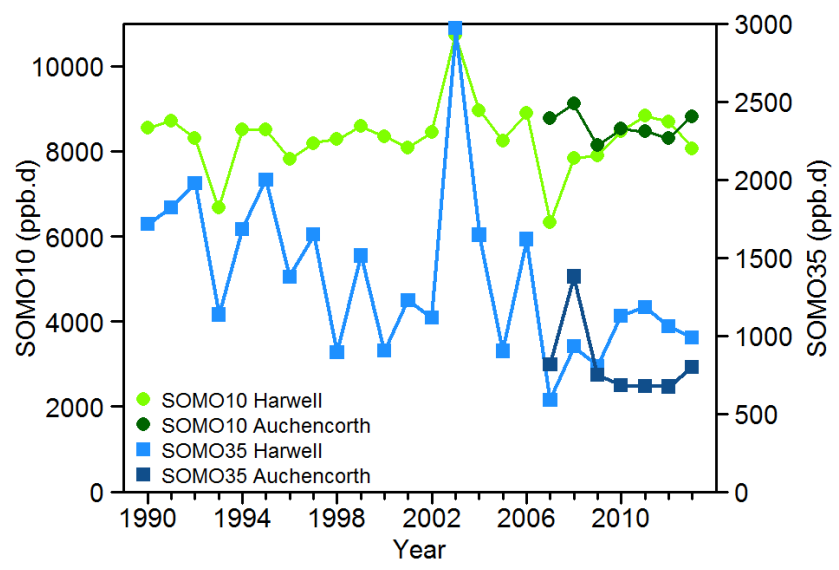

Figure 3. Human health-relevant exposure to $\mathrm{O}_{3}$ at Harwell (19902013) and Auchencorth (2007-2013), as characterised by the SOMO10 and SOMO35 metrics.

whole 24-year period. The contribution to SOMO35 from the higher concentration bins was larger than for SOMO10 but also decreased significantly (Fig. 5b): the 1990-2013 trends in SOMO35 contributions from $\mathrm{O}_{3}$ concentrations between $60-70$ and $>70 \mathrm{ppb}$ were -0.4 and $-1.4 \% \mathrm{y}^{-1}$ respectively. There were significant increases in contributions to SOMO35 from concentrations between 35 and $50 \mathrm{ppb}$ (trends in the range $0.4-1.5 \% \mathrm{y}^{-1}$ ). At Harwell the amplitude of the diurnal $\mathrm{O}_{3}$ cycle was consistently greater (by 7-18ppb) on SOMO35 ADs compared to SOMO35 NADs (Table S1), while the diurnal $\mathrm{NO}$ and $\mathrm{NO}_{2}$ cycles were substantially lower on ADs than on NADs. Figure 6 shows that the mean diurnal amplitudes of $\mathrm{O}_{3}, \mathrm{NO}_{2}$ and $\mathrm{NO}$ on SOMO35 ADs decreased significantly between 1990 and 2013 (trends of $-1.8,-2.8$ and $-3.6 \% \mathrm{y}^{-1}$ respectively). There was also a significant decrease in mean diurnal cycle amplitudes of $\mathrm{O}_{3}, \mathrm{NO}_{2}$ and $\mathrm{NO}$ on SOMO10 ADs (trends of $-1.4,-2.6$ and $-3.9 \% \mathrm{y}^{-1}$ respectively; $\mathrm{NO}_{x}$ data only from 1996). Trends of decreasing diurnal amplitudes were also observed on SOMO35 NADs (note that SOMO10 NADs were rare, and during 2010-2013 there were essentially no SOMO10 NADs).

The largest change in the $\mathrm{O}_{3}$ human health chemical climate drivers between 1990 and 2013 at Harwell was the decrease in the estimated daily averaged $\mathrm{NO}_{x}$ emissions along the air-mass back trajectories (Fig. 7). For SOMO35 ADs and NADs, the decreases were -3.1 and $-3.0 \% \mathrm{y}^{-1}$ respectively, while the decrease on SOMO10 ADs was $-2.9 \% \mathrm{y}^{-1}$ (all $p=0.001$ ). For SOMO10 and SOMO35, temperatures on NADs were lower than on ADs. For SOMO35, the average temperature was $2.3 \pm 1.5^{\circ} \mathrm{C}$ higher on ADs than on NADs between 2010 and 2013, smaller than the corresponding differential of $3.9 \pm 1.3{ }^{\circ} \mathrm{C}$ between 1990 and 1993. The median trend in this temperature differential was $-2.5 \% \mathrm{y}^{-1}$ $(p=0.001)$. The proportion of air-mass back trajectories classified into the four geographic groupings through cluster 

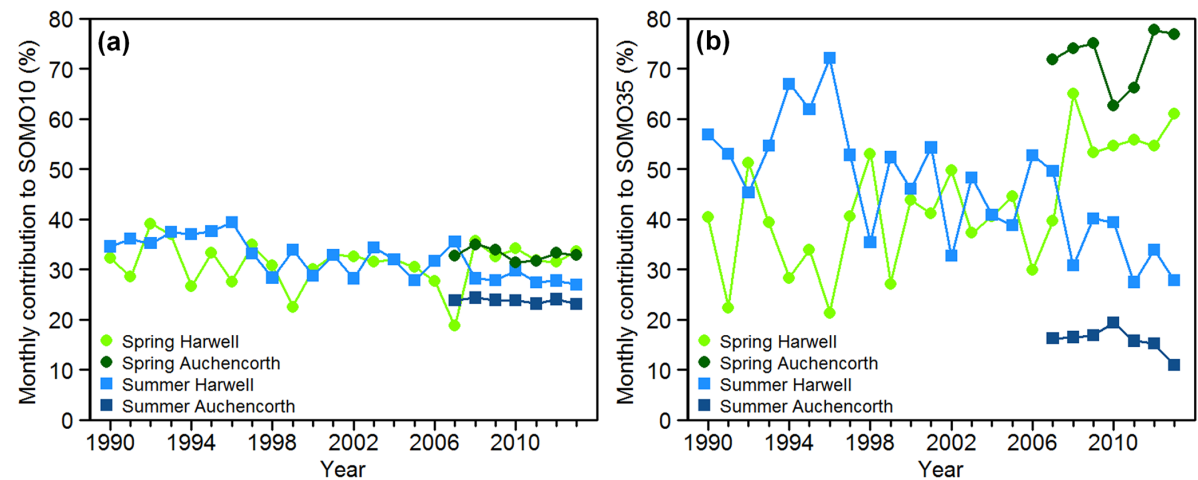

Figure 4. Relative annual contributions from spring (MAM) and summer (JJA) to (a) SOMO10 and (b) SOMO35.
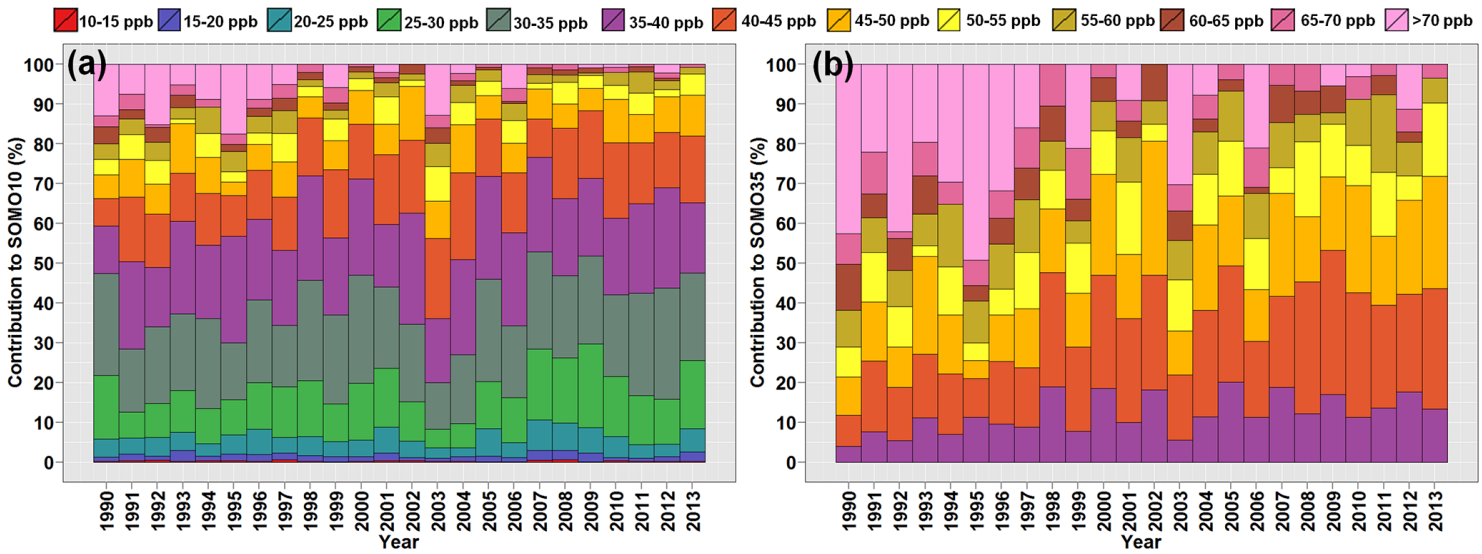

Figure 5. Relative annual contributions to (a) SOMO10 and (b) SOMO35 at Harwell from different $\mathrm{O}_{3}$ concentration bins. Concentrations are separated into $135 \mathrm{ppb}$ bins spanning daily maximum $8 \mathrm{~h}$ mean $\mathrm{O}_{3}$ concentrations between 10 and $>70$ ppb. Note: these concentration bins are contributing to a decreasing long-term trend in SOMO35 and to a constant trend in SOMO10, as illustrated in Fig. 3.

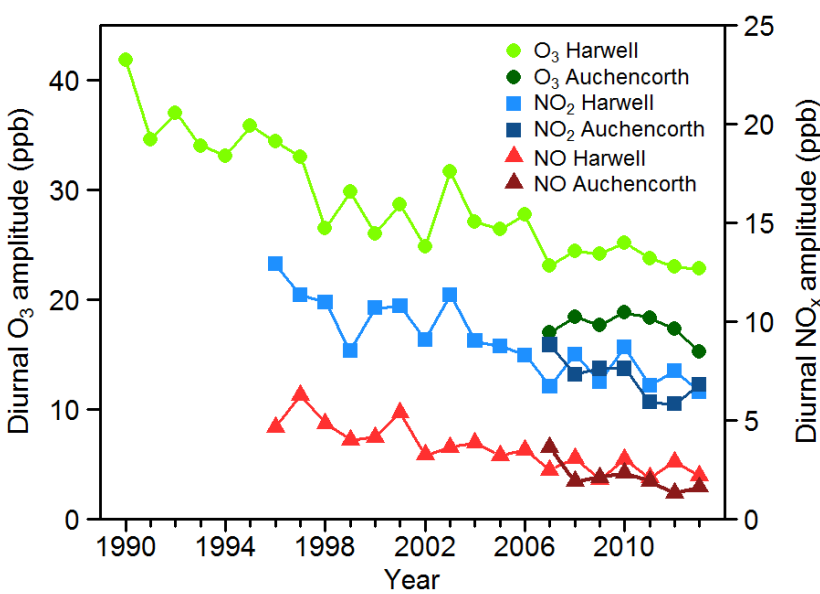

Figure 6. Amplitude of the diurnal $\mathrm{O}_{3}, \mathrm{NO}_{2}$ and $\mathrm{NO}$ cycles at Harwell and Auchencorth during SOMO35 accumulation days (ADs).

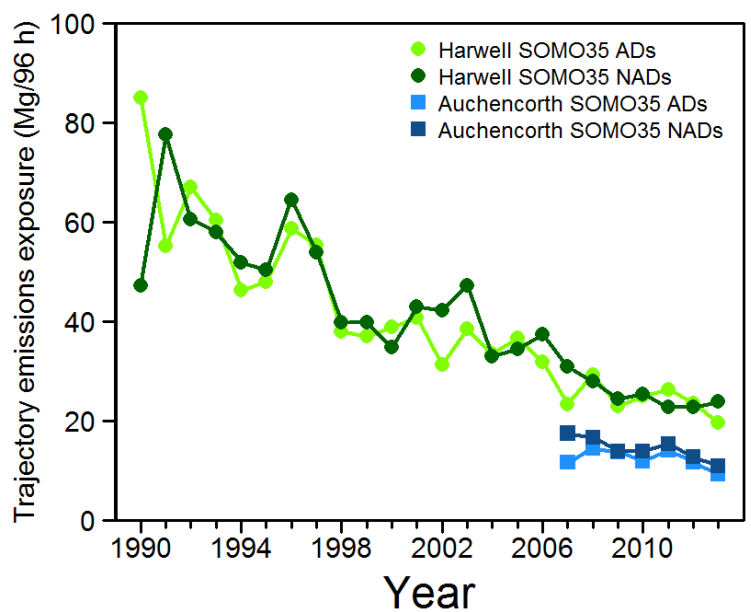

Figure 7. Estimate of the hourly European $\mathrm{NO}_{x}$ emissions emitted from the EMEP $0.5^{\circ}$ grids over which $96 \mathrm{~h}$ back trajectories passed prior to arrival at Harwell and Auchencorth for SOMO35 accumulation days (ADs) and non-accumulation days (NADs). 
analysis did not vary significantly between ADs and NADs for SOMO35 or across the whole 1990-2013 period. In 2003, the effects of long-term changes in the emission drivers were temporarily offset and SOMO10 and SOMO35 values were elevated (Fig. 3). This was due to the "heat-wave" period experienced across south-east England during the summer of that year. The elevated temperatures enhanced $\mathrm{O}_{3}$ concentrations by leading to greater biogenic VOC emissions, increased reactivity of VOCs with $\mathrm{OH}$ and reduced $\mathrm{O}_{3}$ dry deposition (Lee et al., 2006; Vieno et al., 2010).

The trends and differences in the statistics presented for the SOMO10 and SOMO35 metrics for 1990-2013 at Harwell reveal changes in the relative importance to $\mathrm{O}_{3}$ concentrations of hemispheric, regional and local-scale processes in determining the health-relevant $\mathrm{O}_{3}$ exposure at Harwell. Hemispheric background levels of $\mathrm{O}_{3}$ over Europe feature a pronounced spring maximum and summer minimum (Derwent et al., 2013; Parrish et al., 2013). Hence during spring the SOMO35 threshold is exceeded on the majority of days. Derwent et al. (2013) analysed $\mathrm{O}_{3}$ concentrations in nonEuropean influenced air masses and found an increasing trend up to 2008, most strongly observed in winter and spring, followed by a levelling off and decrease. Wilson et al. (2012) also calculated a significant positive trend between 1996 and 2005 in monthly fifth percentile $\mathrm{O}_{3}$ concentrations, taken as a measure of background concentrations, at 82 out of 158 European monitoring sites, including the majority of sites in the UK. This increase in hemispheric background concentrations has led to the increases in the number of winter SOMO10 ADs and in the spring contribution to SOMO35.

Regional $\mathrm{O}_{3}$ production is greatest in summer when solar intensity and temperatures are highest, so the contribution to the $\mathrm{O}_{3}$ exposure associated with the health impact during summer is predominantly of European origin (Jenkin, 2008). Autumn and winter have far fewer SOMO35 ADs because of lower hemispheric background levels and lower solar intensity for regional production; however, the consistent exceedance of $10 \mathrm{ppb}$ during autumn and winter leads to a significant contribution to SOMO10 (approximately $40 \%$ in 2010-2013; Table S1). The decrease in summer contribution to $\mathrm{SOMO} 35$ results from reduced regionally produced $\mathrm{O}_{3}$ episodes. This is evidenced by the reduced contribution from the highest $\mathrm{O}_{3}$ concentration days, the decreased amplitude of diurnal $\mathrm{O}_{3}$ variation during SOMO35 and SOMO10 ADs and the decreased temperature difference between SOMO35 $\mathrm{AD}$ and NADs (regionally generated $\mathrm{O}_{3}$ exhibits a pronounced diurnal cycle due to its photochemical production and is therefore determined to a greater extent by European meteorological conditions than is hemispheric background $\mathrm{O}_{3}$ ). Jenkin (2008) and Munir et al. (2013) likewise attributed long-term decreases in high percentile $\mathrm{O}_{3}$ concentrations at UK monitoring sites to reduced regional photochemical $\mathrm{O}_{3}$ episodes and increases in lower percentile concentrations to increased hemispheric background.
The decrease in regional $\mathrm{O}_{3}$ production is due to the decreasing trend in precursor emissions affecting Harwell (Fig. 7). The European Environment Agency (EEA) estimates that, across the EU28 countries, $\mathrm{NO}_{x}$ emissions have decreased by $51 \%$ between 1990 and 2012 and VOC emissions have decreased by $60 \%$ (EEA, 2014a). Unlike SOMO35, the SOMO10 metric did not decline between 1990 and 2013 because of the lower contribution to SOMO10 from the highest $\mathrm{O}_{3}$ concentrations, which derive from regional photochemical episodes. SOMO10 was therefore less sensitive to decreases in the magnitude of these episodes, and the decrease was offset by an increase in contribution from 20 to $30 \mathrm{ppb}$ daily maximum $8 \mathrm{~h}$ ADs, which were not included in SOMO35.

In summary, whether or not it can be concluded that there has been a decline in $\mathrm{O}_{3}$ exposure associated with human health impact between 1990 and 2013 at Harwell depends on the choice of a 35 or $10 \mathrm{ppb}$ threshold, both of which are recommended in the recent WHO review (REVIHAAP, 2013). Although the absolute health impact apportioned to $\mathrm{O}_{3}$ is sensitive to the choice of threshold (Stedman and Kent, 2008; Heal et al., 2013), the analyses presented here have shown that, irrespective of whether a 35 or $10 \mathrm{ppb}$ threshold is selected, the extent, timing and severity of the human health impact of $\mathrm{O}_{3}$ is increasingly driven by more frequent, modest exceedances of the respective threshold rather than short-lived extreme episodic exceedances.

\subsubsection{Spatial differences between Auchencorth and Harwell (2007-2013)}

In the comparison of Auchencorth (representative of much of the rural west and north of the UK) and Harwell (representative of south-east England), annual mean and 75th percentile $\mathrm{O}_{3}$ concentrations were greater at Auchencorth between 2007 and 2013, while maximum values were substantially greater at Harwell (Tables S1 and S2). Between 2007 and 2013, the average SOMO35 was $14 \%$ lower at Auchencorth, while the average SOMO10 was $7 \%$ higher than Harwell. The proportion of SOMO10 accumulated in spring was similar at both sites, but the proportion accumulated in summer was on average $5.3 \pm 2.9 \%$ lower at Auchencorth. The contribution to SOMO35 from spring was greater at Auchencorth but smaller for summer compared to Harwell (Fig. 4). Auchencorth also had a smaller contribution from days with $>60 \mathrm{ppb}$ daily maximum $8 \mathrm{~h} \mathrm{O}_{3}$ concentrations (Table S2). Mean amplitudes of diurnal $\mathrm{O}_{3}$ variation on SOMO10 and SOMO35 ADs were also smaller at Auchencorth than at Harwell (see Fig. 6 for the data relating to SOMO35 ADs). In addition, the difference in mean amplitudes of diurnal $\mathrm{O}_{3}$, $\mathrm{NO}_{2}$ and $\mathrm{NO}$ variation on SOMO10/35 ADs and NADs was smaller at Auchencorth than at Harwell. For example, diurnal $\mathrm{O}_{3}$ amplitude was 2.2-4.5 ppb greater on SOMO35 ADs than on NADs at Auchencorth (Table S2), which was smaller 
than the 5.6-8.2 ppb differential at Harwell between 2007 and 2013 (Table S1).

The estimated daily averaged $\mathrm{NO}_{x}$ emissions along the airmass back trajectories were substantially lower at Auchencorth than at Harwell (Fig. 7) and generally lower (13 \pm $9 \%$ on average in 2007-2013) on SOMO35 ADs than NADs. The temperature difference between SOMO35 ADs and NADs at Auchencorth was less than at Harwell, ranging between $1.7^{\circ} \mathrm{C}$ higher on average on ADs in 2010 to $1.4^{\circ} \mathrm{C}$ lower on ADs in 2013. Elevated SOMO10 (6\% above 2007-2013 average) and SOMO35 (67\%) values in 2008 at Auchencorth (as also reported by Gauss et al. (2014) using the EMEP/MSC-W model) resulted from an increased contribution from days with maximum $8 \mathrm{~h}$ concentrations above $50 \mathrm{ppb}$ (12 and $36 \%$ contributions to SOMO10 and SOMO35 respectively). In addition, $28 \%$ of trajectories were grouped in an "easterly" cluster on SOMO35 ADs in 2008 compared to $13 \%$ on NADs. Patterns were similar in 2009, 2012 and 2013 but without the elevated SOMO35 compared to 2008. The larger $\mathrm{O}_{3}$ and $\mathrm{NO}_{2}$ diurnal amplitudes on SOMO10 and SOMO35 ADs in 2008 and the elevated temperatures on SOMO35 ADs (Table S2) suggest regional $\mathrm{O}_{3}$ production was a substantially stronger driver of SOMO35 in 2008 compared to other years at Auchencorth.

The chemical climate state and driver statistics for Auchencorth indicate that $\mathrm{O}_{3}$ concentrations at this location are less modified from the hemispheric background than at Harwell, consistent with spatial patterns reported in Jenkin (2008). The larger contribution from spring to SOMO35 at Auchencorth compared to Harwell shows that the hemispheric spring maximum in $\mathrm{O}_{3}$ produces the majority of SOMO35, and the lower contribution from high $\mathrm{O}_{3}$ concentration $\mathrm{ADs}$ indicates lower influence from regional photochemical $\mathrm{O}_{3}$ production. Since SOMO10 is determined to a lesser extent by high $\mathrm{O}_{3}$ concentration ADs, this explains why calculated SOMO35 are lower at Auchencorth, yet SOMO10 values are similar at Auchencorth and Harwell.

\subsubsection{Comparison between SOMO10/SOMO35 and higher threshold metrics}

In spite of these spatial differences between the SOMO10 and SOMO35 metrics, both provide a substantially different picture of the extent (proportion of year over which impact metric is accumulated), timing (particular periods when impact metric is accumulated) and severity (magnitude of impact metric) of human health-relevant $\mathrm{O}_{3}$ exposure at Harwell and Auchencorth compared with use of higher threshold metrics such as the WHO air quality guideline (50 ppb) or the EU target value (60 ppb). For example, in 2013 the extent of exceedance of the $60 \mathrm{ppb}$ EU target value across the UK was only 19 days (at least 1 of 81 UK sites exceeding threshold), and the timing of these exceedances was mainly in summer (EEA, 2014b). In contrast, at Harwell in 2013 there were 356 and 130 ADs for SOMO10 and SOMO35 respectively, of which only 27 and $28 \%$ was accumulated in summer. In respect to severity, during 2010-2013 at Harwell on average 91 and $66 \%$ of SOMO10 and SOMO35 respectively was accumulated on days with maximum $8 \mathrm{~h} \mathrm{O}_{3}$ concentrations below the WHO guideline of $50 \mathrm{ppb}$, compared to 76 and $38 \%$ in 1990-1993 (Table S1). At Auchencorth, an even larger proportion of SOMO10 and SOMO35 were accumulated below $50 \mathrm{ppb}$, on average 96 and $84 \%$ respectively, during the 2007-2013 monitoring period (Table S2).

The overall impression from these statistics showing a decline in exposure to concentrations in excess of $35 \mathrm{ppb}$ is that the threat to human health has declined between 1990 and 2013 in south-east England. The comments from the EEA (2014b) on the very few episodes in excess of 50 or $60 \mathrm{ppb}$ in 2013 are consistent with this view. However, the recent REVIHAAP (2013) synthesis shows that the lower percentiles of $\mathrm{O}_{3}$ are also important and it is hard to define a precise threshold below which $\mathrm{O}_{3}$ is not harmful. Thus the dose of $\mathrm{O}_{3}$ to humans through respiration may be the more important guide to the potential threat, and as the SOMO10 (and the mean values) have changed little with time, the suggested improvement in air quality from the EEA may be more apparent than real. An important policy implication of these trends is the degree to which local, regional or global policies are required to decrease the threat to human health from $\mathrm{O}_{3}$. In the case of exposures to $\mathrm{O}_{3}$ in excess of $60 \mathrm{ppb}$, controls at the European and national scales can be effective, as the measurements demonstrate. However, if the mean or lower percentiles are important, as suggested in recent syntheses, then controls at much larger (hemispheric) scales are required.

\section{2 $\mathrm{O}_{3}$ vegetation-impact chemical climates}

The detailed statistics describing the impacts of $\mathrm{O}_{3}$ on crops at Harwell and Auchencorth, as derived using the PODY metric, are presented in Tables S3 and S4 for potato and Tables S5 and S6 for wheat, and as derived using the generic crop AOT40 metric for a May-July growing season in Tables S7 and S8. The statistics for the PODY metric for forest trees are presented in Tables S9 and S10 for beech, and Tables S11 and S12 for Scots pine. The PODY statistics presented in Tables S5-S12, and Figs. 8-13 were calculated for the loam (medium) soil texture (Büker et al., 2012). The representativeness of the conclusions derived from the interpretation of these statistics to other soil textures is discussed in Sect. 3.2.1 and 3.2.2. This section presents two analyses of the impact, state and drivers of the chemical climatology framework (Fig. 2, steps 1-5); specifically, changes in chemical climate phase (Fig. 2, Step 6) temporally at Harwell between 1990 and 2013 (Sect. 3.2.1) and spatially between Auchencorth and Harwell (Sect. 3.2.2). 

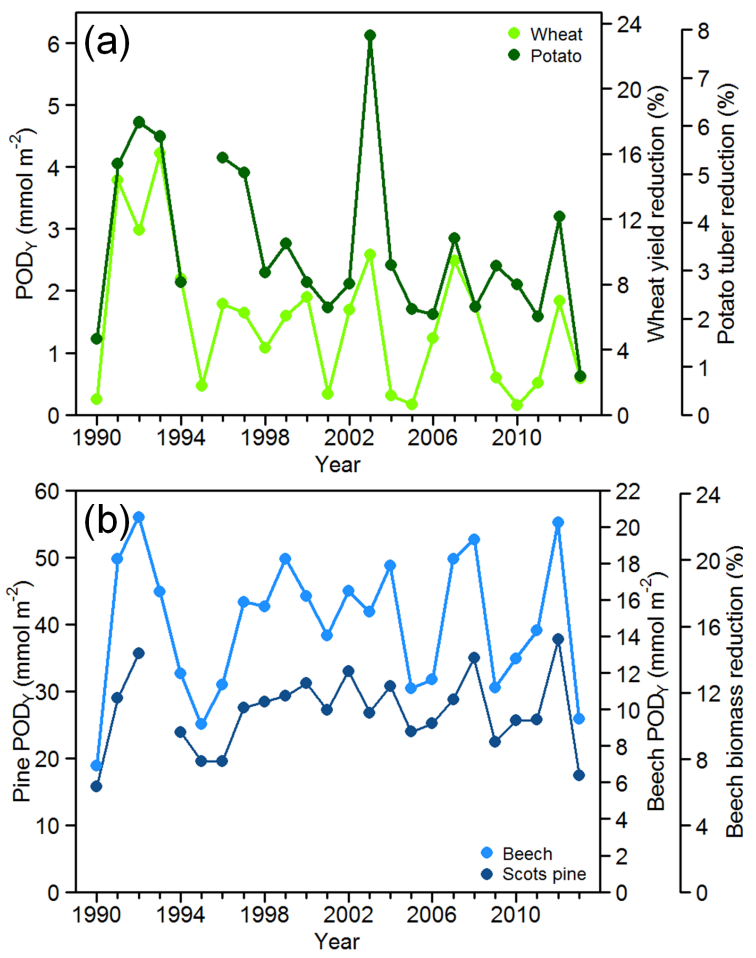

Figure 8. Impact of $\mathrm{O}_{3}$ characterised by the PODY metric (and associated response) for (a) wheat (grain yield reduction), potato (tuber weight reduction), (b) beech (biomass reduction) and Scots pine at Harwell between 1990 and 2013.

\subsubsection{Long-term changes in vegetation impact at Harwell (1990-2013)}

Figure 8 shows the impact of $\mathrm{O}_{3}$ on vegetation at Harwell, as quantified by the relevant $\mathrm{PODY}_{\mathrm{Y}}$ and response (grain yield for wheat, tuber weight for potato and biomass reduction for beech). The 1990-2013 average PODY values calculated using sandy loam (coarse), silt loam (medium coarse), loam (medium) and clay loam (fine) soil texture properties are shown in Table 1. The ratio between the largest and small-

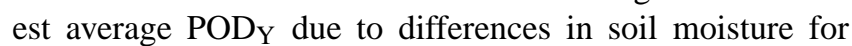
the different soil textures was 1.57 (wheat), 1.32 (potato), 1.14 (beech) and 1.10 (Scots pine), but the annual pattern of PODY accumulation was consistent across the four soil textures. The statistics in the following sections are those calculated for the loam soil texture, unless otherwise stated, which has intermediate hydraulic properties compared with the three other soil textures.

For crops, there has not been a statistically significant change in PODY between 1990 and 2013, across all soil textures. Using the critical levels for adverse vegetation damage agreed by the UN Convention on Long-range Transboundary Air Pollution (LRTAP; Mills et al., 2011c), $\mathrm{O}_{3}$ has a greater impact on wheat than potato at Harwell, with 13 of the 24 years exceeding the $5 \%$ yield reduction critical

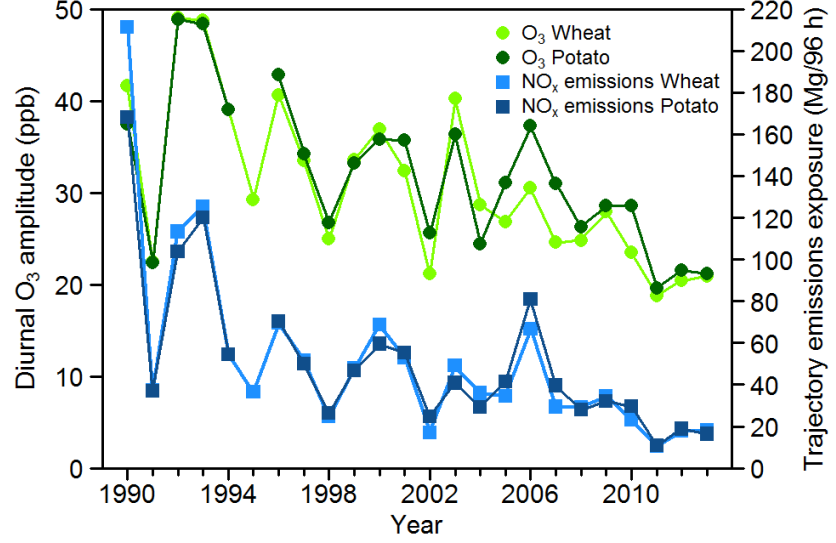

Figure 9. Amplitude of the diurnal $\mathrm{O}_{3}$ cycle at Harwell during June PODY accumulation days for wheat and potato and hourly European $\mathrm{NO}_{x}$ emission estimate for the EMEP $0.5^{\circ}$ grids over which $96 \mathrm{~h}$ back trajectories passed prior to arrival at Harwell during June PODY accumulation days for wheat and potato.

level for wheat, compared to 6 years exceeding the $5 \%$ tuber weight reduction critical level for potato. Mills et al. (2011a), using modelled $\mathrm{O}_{3}$ and meteorological data to assess the impact of $\mathrm{O}_{3}$ on vegetation across the UK in 2006 and 2008, also reported a smaller impact on potato than wheat, due to the lower sensitivity of potato to $\mathrm{O}_{3}$.

The majority of $\mathrm{POD}_{\mathrm{Y}}$ accumulation for potato and wheat occurred in June (Tables S3 and S5). Between 1990 and 2013 there were significant decreases in diurnal $\mathrm{O}_{3}, \mathrm{NO}_{2}$ and NO amplitudes on June ADs (Fig. 9, Tables S3 and S5). The median trend in diurnal $\mathrm{O}_{3}$ amplitude on June ADs was -2.0 and $-2.4 \% \mathrm{y}^{-1}$ for potato and wheat respectively ( $p=0.001)$, and, in the latter period (2010-2013), the difference in diurnal $\mathrm{O}_{3}$ amplitude between June ADs and NADs was small (Tables S3 and S5). Figure 10 shows the percentage of $\mathrm{POD}_{\mathrm{Y}}$ accumulated during different measured hourly $\mathrm{O}_{3}$ concentration ranges. There were significant decreasing trends in the contribution from the highest concentration bins $(65-70 \mathrm{ppb}$ and $>70 \mathrm{ppb})$ for potato $\left(-0.4--1.4 \% \mathrm{y}^{-1}\right)$ and from the 55-60 and 65-70 ppb concentrations bins for wheat. In contrast, there were increasing trends in $\mathrm{POD}_{\mathrm{Y}}$ contribution from the $25-45 \mathrm{ppb} \mathrm{O}_{3}$ concentration bins for potato $\left(0.1-0.8 \% \mathrm{y}^{-1}\right)$ and from the $30-45 \mathrm{ppb}$ concentration bins for wheat $\left(0.5-1.1 \% \mathrm{y}^{-1}\right)$. These trends were due to a decreasing frequency of hours with $\mathrm{O}_{3}$ concentrations in the range between 55 and $>70 \mathrm{ppb}$ during the growing seasons of potato $\left(-3.0--4.3 \% \mathrm{y}^{-1}\right)$ and wheat $\left(-2.1--4.8 \% \mathrm{y}^{-1}\right)$ and increasing frequency of hourly $\mathrm{O}_{3}$ concentrations in the range $25-45 \mathrm{ppb}$ (wheat) and 20-35 ppb (potato). For both crops, the estimated back-trajectory $\mathrm{NO}_{x}$ emissions on ADs decreased significantly in the period 1990-2013 for each month of the growing season (Fig. 9 shows this decrease for ADs in June), with trends ranging from -2.5 to $-4.3 \% \mathrm{y}^{-1}$. Other drivers such as temperature, global radia- 
Table 1. Average \pm SD wheat, potato, beech and Scots pin PODY $_{Y}$ calculated for four different soil textures (see Bueker et al., 2012, for a description of their hydraulic properties) over the monitoring periods at Harwell and Auchencorth.

\begin{tabular}{|c|c|c|c|c|}
\hline & Sandy loam (coarse) & Silt loam (medium coarse) & Loam (medium) & Clay loam (fine) \\
\hline \multicolumn{5}{|c|}{ Harwell 1990-2013 average } \\
\hline $\begin{array}{l}\text { Wheat PODY }\left(\mathrm{mmol} \mathrm{m}^{-2}\right) \\
\text { (grain yield \% reduction) }\end{array}$ & $\begin{array}{l}1.21 \pm 1.07 \\
(4.61 \%)\end{array}$ & $\begin{array}{l}1.75 \pm 1.19 \\
(6.64 \%)\end{array}$ & $\begin{array}{l}1.51 \pm 1.14 \\
(5.72 \%)\end{array}$ & $\begin{array}{l}1.90 \pm 1.19 \\
(7.22 \%)\end{array}$ \\
\hline $\begin{array}{l}\text { Potato } \mathrm{POD}_{\mathrm{Y}}\left(\mathrm{mmol} \mathrm{m}^{-2}\right) \\
\text { (tuber yield \% reduction) }\end{array}$ & $\begin{array}{l}2.35 \pm 1.27 \\
(3.03 \%)\end{array}$ & $\begin{array}{c}3.10 \pm 1.42 \\
(3.99 \%)\end{array}$ & $\begin{array}{c}2.64 \pm 1.32 \\
(3.40 \%)\end{array}$ & $\begin{array}{l}3.10 \pm 1.46 \\
(4.00 \%)\end{array}$ \\
\hline $\begin{array}{l}\text { Beech PODY }\left(\mathrm{mmol} \mathrm{m}^{-2} \text { ) }\right. \\
\text { (biomass \% reduction) }\end{array}$ & $\begin{array}{c}14.0 \pm 3.7 \\
(15.4 \%)\end{array}$ & $\begin{array}{c}16.0 \pm 3.5 \\
(17.6 \%)\end{array}$ & $\begin{array}{c}14.7 \pm 3.7 \\
(16.2 \%)\end{array}$ & $\begin{array}{c}16.1 \pm 3.4 \\
(17.7 \%)\end{array}$ \\
\hline Pine PODY $\left(\mathrm{mmol} \mathrm{m}^{-2}\right)$ & $26.2 \pm 5.5$ & $28.7 \pm 5.3$ & $27.0 \pm 5.6$ & $28.8 \pm 5.3$ \\
\hline \multicolumn{5}{|c|}{ Auchencorth 2007-2013 average } \\
\hline $\begin{array}{l}\text { Wheat PODY }\left(\mathrm{mmol} \mathrm{m}^{-2} \text { ) }\right. \\
\text { (grain yield \% reduction) }\end{array}$ & $\begin{array}{l}0.85 \pm 0.45 \\
(3.23 \%)\end{array}$ & $\begin{array}{c}1.01 \pm 0.38 \\
(3.86 \%)\end{array}$ & $\begin{array}{l}0.96 \pm 0.39 \\
(3.65 \%)\end{array}$ & $\begin{array}{l}1.05 \pm 0.37 \\
(3.99 \%)\end{array}$ \\
\hline $\begin{array}{l}\text { Potato PODY }\left(\mathrm{mmol} \mathrm{m}^{-2}\right) \\
\text { (tuber yield } \% \text { reduction) }\end{array}$ & $\begin{array}{l}0.95 \pm 0.41 \\
(1.22 \%)\end{array}$ & $\begin{array}{l}1.08 \pm 0.46 \\
(1.39 \%)\end{array}$ & $\begin{array}{l}0.99 \pm 0.41 \\
(1.28 \%)\end{array}$ & $\begin{array}{c}1.09 \pm 0.47 \\
(1.40 \%)\end{array}$ \\
\hline $\begin{array}{l}\text { Beech PODY }\left(\mathrm{mmol} \mathrm{m}^{-2}\right) \\
\text { (biomass \% reduction) }\end{array}$ & $\begin{array}{l}16.6 \pm 1.6 \\
(18.3 \%)\end{array}$ & $\begin{array}{c}16.9 \pm 1.2 \\
(18.6 \%)\end{array}$ & $\begin{array}{c}16.7 \pm 1.5 \\
(18.4 \%)\end{array}$ & $\begin{array}{c}16.9 \pm 1.2 \\
(18.6 \%)\end{array}$ \\
\hline Pine PODY $\left(\mathrm{mmol} \mathrm{m}^{-2}\right)$ & $35.9 \pm 3.6$ & $36.5 \pm 2.7$ & $36.2 \pm 3.3$ & $36.6 \pm 2.7$ \\
\hline
\end{tabular}

(a)
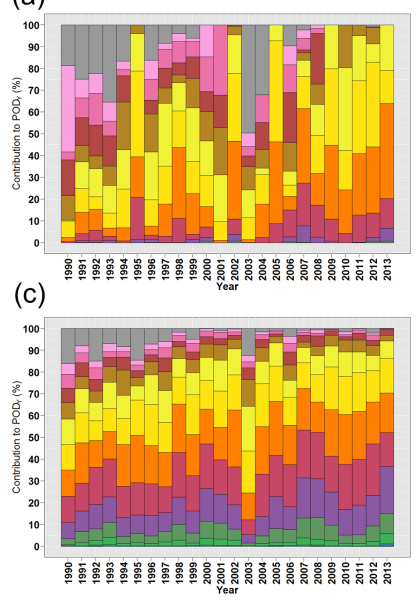

(b)

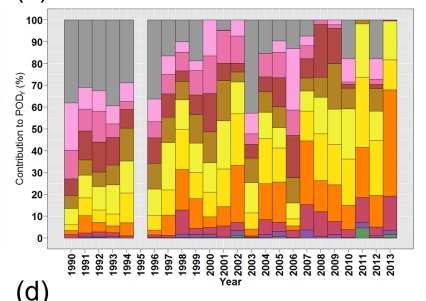

(d)

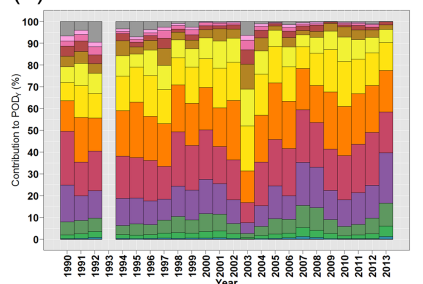

$\square_{0-5 \mathrm{ppb}} \square_{5-10 \mathrm{ppb}} \square^{10-15 \mathrm{ppb}} \square_{15-20} \mathrm{ppb} \square_{20-25 \mathrm{ppb}} \square_{25-30 \mathrm{ppb}} \square_{30-35} \mathrm{ppb} \square_{35-40 \mathrm{ppb}}$

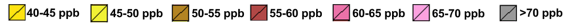

Figure 10. Relative annual contributions to (a) wheat $P_{Y}$, (b) potato PODY, (c) beech PODY and (d) Scots pine PODY at Harwell from different $\mathrm{O}_{3}$ concentration bins. Concentrations are separated into $155 \mathrm{ppb}$ groups spanning hourly $\mathrm{O}_{3}$ concentrations between $0 \mathrm{ppb}$ and $>70 \mathrm{ppb}$. Note: these concentration bins are contributing to constant trends in PODY for each vegetation type - see Fig. 7.

tion and back-trajectory pathway did not change significantly between 1990 and 2013 (Tables S3 and S5).

For beech and Scots pine, there was no significant trend in PODY between 1990 and 2013 across all soil types (Fig. 8).
The average PODY $_{Y}$ for beech (Table 1) was 4 times the critical level (Mills et al., 2011c). Beech and Scots pine PODY values were substantially higher than for the crops, due to a lower threshold for exceedance, a longer growing season and other differences in the stomatal conductance response to $T$, PAR, VPD and SWP. The average beech PODY value calculated here is comparable with the estimate for beech PODY modelled by Simpson et al. (2007) for the south-east of England $\left(8-16 \mathrm{mmol} \mathrm{m}^{-2}\right)$, but both values were higher than the values estimated in Emberson et al. (2007) for three European climate regions (not including UK) in 1997.

The low $1 \mathrm{nmol} \mathrm{m}^{-2} \mathrm{~s}^{-1}$ threshold for POD $\mathrm{Y}$ accumulation for beech and Scots pine was exceeded during the majority of days during the respective growing seasons. The major contributions by month to $\mathrm{POD}_{\mathrm{Y}}$ were consistently May and June for beech and April, May and June for Scots pine (Tables S9 and S11). During 1990-2013 diurnal $\mathrm{O}_{3}$ amplitude decreased significantly on beech and Scots pine ADs between May and September, with median monthly AD trends between -1.5 and $-2.3 \% \mathrm{y}^{-1}$ for beech and -1.3 and $-2.4 \% \mathrm{y}^{-1}$ for Scots pine. Across the 24-year period there was a more consistent major contribution to $\mathrm{POD}_{\mathrm{Y}}$ during hourly $\mathrm{O}_{3}$ concentrations in the range $25-50 \mathrm{ppb}$ compared to wheat and potato, especially for Scots pine (Fig. 10c and d). For beech and Scots pine, the trends in contribution from different concentration bins were smaller compared to crops. Decreasing trends in POD $_{Y}$ contribution were significant for concentration bins between 50 and $>70 \mathrm{ppb}(-0.1-$ $-0.4 \% \mathrm{y}^{-1}$ for beech and $-0.1--0.2 \% \mathrm{y}^{-1}$ for Scots pine), and significant increasing trends in more moderate concen- 
tration bins (25-40 ppb) were only apparent for beech. During the growing season of each tree, the frequency of high $\mathrm{O}_{3}$ concentrations (between 55 and $>70 \mathrm{ppb}$ ) decreased significantly $\left(-2.5--5.3 \% \mathrm{y}^{-1}\right.$ for both trees), and there was an increase in the frequency of concentrations between 25 and $35 \mathrm{ppb}\left(+1.4-+2.2 \% \mathrm{y}^{-1}\right.$ for both trees). Karlsson et al. (2007) calculated a similar result for Norway Spruce in Sweden, where between 2002-2004 approximately $80 \%$ of $\mathrm{POD}_{\mathrm{Y}}$ was accumulated during $\mathrm{O}_{3}$ concentrations between 30 and $50 \mathrm{ppb}$. The estimated $\mathrm{NO}_{x}$ emissions into the airmass trajectories also decreased significantly during beech and Scots pine ADs, with median monthly trends ranging from -3.2 to $-3.6 \% \mathrm{y}^{-1}$ for beech and -1.9 to $-3.7 \% \mathrm{y}^{-1}$ for Scots pine.

The significant trends in state (pollutant diurnal variation and concentration bin contributions) and drivers (trajectory emission estimates) for the four vegetation types (Fig. 9 and Tables S3, S5, S9 and S11) indicate an increase in the relative importance of hemispheric background $\mathrm{O}_{3}$ concentrations in determining $\mathrm{POD}_{\mathrm{Y}}$. Despite this change $\mathrm{POD}_{\mathrm{Y}}$ values have not decreased, in contrast to SOMO35, for which decreased contribution from high $\mathrm{O}_{3}$ concentrations (produced during regional $\mathrm{O}_{3}$ episodes) resulted in a decreasing trend. This was due to non- $\mathrm{O}_{3}$ factors such as stomatal response to VPD and soil moisture which also determine the severity of a vegetation impact by limiting the $\mathrm{O}_{3}$ flux during high $\mathrm{O}_{3}$ concentration episodes, reducing the sensitivity of $\mathrm{POD}_{\mathrm{Y}}$ values to decreases in regional $\mathrm{O}_{3}$ production. For example, during the potato growing season the median stomatal conductance during hours with $\mathrm{O}_{3}$ concentrations in the ranges 60 $65,65-70$ and $>70 \mathrm{ppb}$ were 86,90 and $65 \mathrm{mmol} \mathrm{m}^{-2} \mathrm{~s}^{-1}$ respectively (median across 1990-2013). These are significantly lower than the maximum stomatal conductance for potato of $750 \mathrm{mmol} \mathrm{m}^{-2} \mathrm{~s}^{-1}$ (LRTAP Convention, 2010) and similar to the median stomatal conductances calculated during more moderate $\mathrm{O}_{3}$ concentrations, such as $35-40 \mathrm{ppb}$ $\left(54 \mathrm{mmol} \mathrm{m}^{-2} \mathrm{~s}^{-1}\right), 40-45 \mathrm{ppb}\left(68 \mathrm{mmol} \mathrm{m}^{-2} \mathrm{~s}^{-1}\right)$ and $45-$ $50 \mathrm{ppb}\left(87 \mathrm{mmol} \mathrm{m}^{-2} \mathrm{~s}^{-1}\right)$.

Soil water potential is a soil-texture-dependent determinant of potato stomatal conductance in the $\mathrm{DO}_{3} \mathrm{SE}$ model, which decreases when SWP is lower than $-0.5 \mathrm{MPa}$ (LRTAP Convention, 2010; Büker et al., 2012). The 19902013 average SWP during hours when $\mathrm{O}_{3}$ concentrations at Harwell were in the concentration ranges 60-65, 65-70 and $>70 \mathrm{ppb}$ were $-1.50 \pm 1.32 \mathrm{MPa},-1.14 \pm 0.93 \mathrm{MPa}$ and $-1.10 \pm 0.90 \mathrm{MPa}$ respectively for the clay loam (fine) soil texture. The average SWP during these $\mathrm{O}_{3}$ concentration ranges were lower and even more limiting for the other three soil textures. These are substantially lower than the average SWP for the $\mathrm{O}_{3}$ concentration ranges between 25 and $50 \mathrm{ppb}$, all of which are above the $-0.5 \mathrm{MPa}$ cut-off except 45-50 ppb for sandy loam, silt loam and loam soil textures (average SWP of $-0.65,-0.52$ and $-0.58 \mathrm{MPa}$ respectively). Across all soil textures, reduction in the frequency of elevated $\mathrm{O}_{3}$ concentrations produced during regional photo- chemical episodes has therefore not reduced $\mathrm{POD}_{\mathrm{Y}}$, as these elevated $\mathrm{O}_{3}$ concentrations coincided with other factors (e.g. SWP) which limit stomatal conductance and hence any potential increase in $\mathrm{O}_{3}$ accumulation resulting from increased $\mathrm{O}_{3}$ concentrations. Decreasing regional $\mathrm{O}_{3}$ production resulted in the largest change in concentration bin contributions for potato $\mathrm{POD}_{\mathrm{Y}}$ (Fig. 10b). This is due to a later growing season than wheat and a shorter accumulation period and higher maximum stomatal conductance than forest trees (150 and $180 \mathrm{mmol} \mathrm{m}^{-2} \mathrm{~s}^{-1}$ for beech and Scots pine respectively compared to $750 \mathrm{mmol} \mathrm{m}^{-2} \mathrm{~s}^{-1}$ for potato), limiting the $\mathrm{O}_{3}$ flux during high $\mathrm{O}_{3}$ episodes.

These non- $\mathrm{O}_{3}$ factors, such as SWP, also determine the annual pattern of POD $_{Y}$ accumulation. For example, between 2010 and 2013 at Harwell the average SWP on potato ADs in June was $-0.11 \mathrm{MPa}$ compared to $-0.72 \mathrm{MPa}$ on NADs (loam soil texture). Hence in June $\mathrm{O}_{3}$ concentrations were sufficient that, when plant conditions were favourable, accumulation of PODY occurred. In July, SWP was substantially higher due to increased temperatures (2010-2013 average SWP on potato ADs was -1.02 MPa). This, combined with decreasingly favourable potato and wheat phenology and reduced potato and wheat stomatal conductance, led to a smaller contribution to total $\mathrm{POD}_{\mathrm{Y}}$ in July than in June. Higher $\mathrm{O}_{3}$ concentrations were therefore needed to accumulate $\mathrm{POD}_{\mathrm{Y}}$; these occurred during regional photochemical $\mathrm{O}_{3}$ production, hence the larger difference between diurnal $\mathrm{O}_{3}$ amplitude on AD and NADs in July than in June for the two crops.

For beech and Scots pine, the proportion of $\mathrm{POD}_{\mathrm{Y}}$ accumulated in May and June was higher than in July and August, despite no change in phenology used in the $\mathrm{DO}_{3} \mathrm{SE}$ model from May to August, and exceedance of the $1 \mathrm{mmol} \mathrm{m}^{-2} \mathrm{~s}^{-1}$ threshold on the majority of days. For beech, reduction in stomatal conductance occurs when SWP is lower than $-0.8 \mathrm{MPa}$ (LRTAP Convention, 2010). Between 2010 and 2013, across the four soil textures, on average 0 and $0-9 \%$ of hourly SWP values in May and June respectively were below this value, compared to $23-51$ and $18-31 \%$ in July and August respectively. The effect of SWP on stomatal conductance begins at $-0.7 \mathrm{MPa}$ for Scots pine and therefore has a larger limiting effect. SWP was also found to be one of the most important limiting factors in determining the impact of $\mathrm{O}_{3}$ on forests across Europe (Emberson et al., 2007). Clay loam had the highest SWP of the four soil textures and therefore the lowest limitation to stomatal conductance, followed by silt loam, loam and sandy loam. However, the variation in soil moisture between different soil textures due to differences in the extent of evaporation is sufficiently small that the lack of long-term trend in PODY $_{Y}$ and annual pattern of accumulation is consistent across the soil textures. 

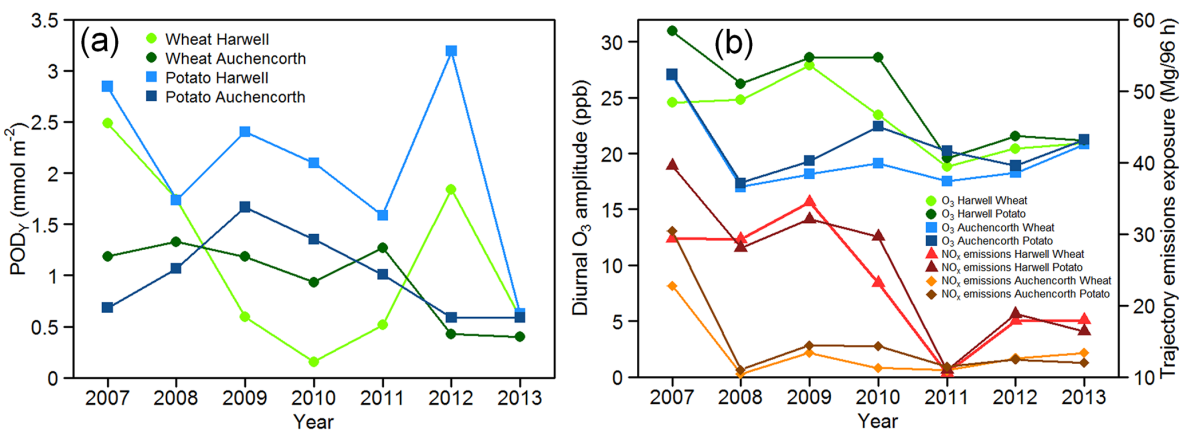

Figure 11. Comparison of $\mathrm{O}_{3}$ vegetation impact chemical climates for wheat and potato 2007-2013: (a) annual PODY for wheat and potato, (b) diurnal $\mathrm{O}_{3}$ amplitude during June accumulation days (ADs) at Harwell and Auchencorth and trajectory $\mathrm{NO}_{x}$ emission estimates at Harwell and Auchencorth.
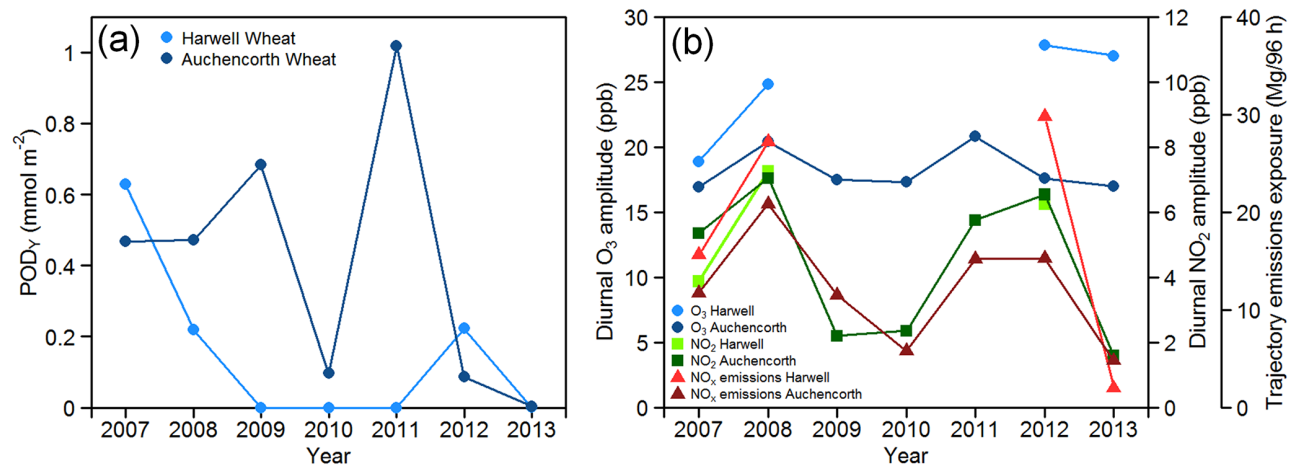

Figure 12. (a) Wheat PODY accumulated during July at Harwell and at Auchencorth, 2007-2013. (b) Diurnal cycle amplitude of $\mathrm{O}_{3}$ and $\mathrm{NO}_{2}$ and back-trajectory $\mathrm{NO}_{x}$ emission estimates during wheat accumulation days (ADs) in July at Harwell and at Auchencorth, 2007-2013.

\subsubsection{Spatial differences between Auchencorth and Harwell (2007-2013)}

The 2007-2013 average POD $_{Y}$ calculated for the four soil textures is shown in Table 1, and the variation between soil textures is less than at Harwell. The ratio between the largest and smallest average POD $_{Y}$ due to differences in soil moisture for the different soil textures was 1.24 (wheat), 1.15 (potato), 1.02 (beech) and 1.02 (Scots pine). The pattern of accumulation, as well as spatial differences between Harwell and Auchencorth, were consistent across soil textures. Annual $\mathrm{POD}_{\mathrm{Y}}$ for potato at Auchencorth (Table S4) was consistently lower than at Harwell, while $\mathrm{POD}_{\mathrm{Y}}$ for wheat were higher at Auchencorth (Table S6) for 3 of the 7 years. The LRTAP critical level for impact (Mills et al., 2011c) was only exceeded at this site in 2008 for wheat $(5.04 \%$ yield reduction). These observations, determined using measured $\mathrm{O}_{3}$ and meteorological data, are consistent with the spatial patterns identified by Mills et al. (2011a) in which modelled $\mathrm{O}_{3}$ and meteorological variables were used to model PODY in $10 \times 10 \mathrm{~km}$ grids across the UK. However, the calculated 2008 tuber weight reduction of $1.4 \%$ for potato at Auchencorth is higher than the $0 \%$ reduction estimated for the grids containing Auchencorth. Simpson et al. (2007) also modelled wheat POD $_{Y}$ across Europe for 2000 and calculated PODY in south-east Scotland at $0.5-1 \mathrm{mmol} \mathrm{m}^{-2}$ and in south-east England at $1-3 \mathrm{mmol} \mathrm{m}^{-2}$, which are similar values to those determined here using the measurement data at Harwell and Auchencorth. In general, diurnal amplitudes of $\mathrm{O}_{3}, \mathrm{NO}_{2}$ and $\mathrm{NO}$ and back-trajectory $\mathrm{NO}_{x}$ emission estimates were lower at Auchencorth (shown in Fig. 11b for wheat and potato PODY $_{Y}$ ADs in June), which indicates a greater importance of hemispheric background concentrations in determining the $\mathrm{O}_{3}$ impact at Auchencorth on wheat and potato.

Periods with elevated regional $\mathrm{O}_{3}$ influence at Auchencorth can lead to a larger effect on $\mathrm{POD}_{\mathrm{Y}}$ compared to Harwell. For example, in 2008 across all soil textures July contributed $0.47 \mathrm{mmol} \mathrm{m}^{-2}$ (36\% total) to wheat PODY (Fig. 12a). In this month, $\mathrm{O}_{3}$ concentrations at Auchencorth had a significant regional photochemical contribution, evidenced by elevated diurnal $\mathrm{O}_{3}$ and $\mathrm{NO}_{2}$ variation and $71 \%$ higher back-trajectory $\mathrm{NO}_{x}$ emissions on ADs compared to the 2007-2013 average (Fig. 12b). PODY in July 2011 at Auchencorth was also influenced by regional $\mathrm{O}_{3}$ production. Diurnal $\mathrm{O}_{3}$ amplitude in July 2011 was 6 ppb higher on ADs than on NADs and global radiation during ADs was $26 \%$ higher than the AD average. July 2011 contributed $80 \%$ of the annual wheat $\mathrm{POD}_{\mathrm{Y}}$ at Auchencorth across all soil tex- 
tures. At Harwell in July 2008, wheat PODY was less than half the Auchencorth value, and in July 2011 there was no PODY accumulation despite elevated regional $\mathrm{O}_{3}$ influence in both cases. These two examples demonstrate that elevated regional photochemical $\mathrm{O}_{3}$ production can have a larger crop impact, characterised through $\mathrm{POD}_{\mathrm{Y}}$, in south-east Scotland than in south-east England, despite being further from major sources of $\mathrm{O}_{3}$ precursor emissions. The meteorological conditions conducive to regional photochemical $\mathrm{O}_{3}$ production (higher temperature and global radiation) at Harwell resulted in unfavourable conditions for high $\mathrm{O}_{3}$ stomatal conductance in crops compared to Auchencorth. The median daytime $\mathrm{O}_{3}$ stomatal conductance was 58 and $63 \mathrm{mmol} \mathrm{m}^{-2} \mathrm{~s}^{-1}$ in July 2008 and 2011 respectively for loam soil texture at Harwell, compared to 94 and $95 \mathrm{mmol} \mathrm{m}^{-2} \mathrm{~s}^{-1}$ at Auchencorth. Average SWP in July 2008 and 2011 was respectively -0.03 and $-0.02 \mathrm{MPa}$ at Auchencorth and -0.63 and $-1.17 \mathrm{MPa}$ at Harwell. In addition, lower temperatures at Auchencorth result in a longer accumulated temperature growing season. In July 2008 and 2011, the phenological limitation on wheat stomatal conductance was similar for the first 3 weeks of the month at both sites but diverged in the final week and was substantially more limiting at Harwell at the end of July (40 and $50 \%$ lower in 2008 and 2011 respectively), also resulting in less favourable conditions for $\mathrm{POD}_{\mathrm{Y}}$ accumulation in south-east England.

Between 2007 and 2013, Scots pine and beech POD were on average 27-37 and 5-19\% higher at Auchencorth compared to Harwell across the soil textures (Table 1 and Fig. 13a). These larger values were due to larger contributions from July and August at Auchencorth (Tables S10 and S12). In these months, higher temperatures at Harwell produced conditions which reduced stomatal conductance. For example, during 2007-2013 at Harwell for loam soil texture, SWP was on average $59 \%$ higher in July and $82 \%$ higher in August than at Auchencorth.

Elevated regional photochemical $\mathrm{O}_{3}$ production also had varying impacts on forest trees at the two sites. In May 2008 across all soil textures, accumulated $\mathrm{POD}_{\mathrm{Y}}$ was elevated at Auchencorth for both Scots pine and beech (Fig. 13b). Larger diurnal $\mathrm{O}_{3}$ variation (28\% higher than the 2007-2013 average) and back-trajectory $\mathrm{NO}_{x}$ emissions (53\% higher) during May 2008 indicate regional photochemical $\mathrm{O}_{3}$ production made a significant contribution to measured $\mathrm{O}_{3}$ concentrations at Auchencorth (Fig. 13c). Despite larger increases in these variables at Harwell, the accumulated PODY in May 2008 was 14 and $29 \%$ less than at Auchencorth for beech and Scots pine respectively across all soil textures (Fig. 13b), and the frequency of hours with high $\mathrm{POD}_{\mathrm{Y}}$ accumulation was lower at Harwell. For example, the maximum hourly PODY accumulated at Harwell and Auchencorth in May 2008 were 0.027 and $0.033 \mathrm{mmol} \mathrm{m}^{-2}$ respectively and there were 21 fewer hours when hourly PODY accumulated was above $0.02 \mathrm{mmol} \mathrm{m}^{-2}$ compared to Auchencorth. Hence the conditions during this regional $\mathrm{O}_{3}$ episode at Harwell,
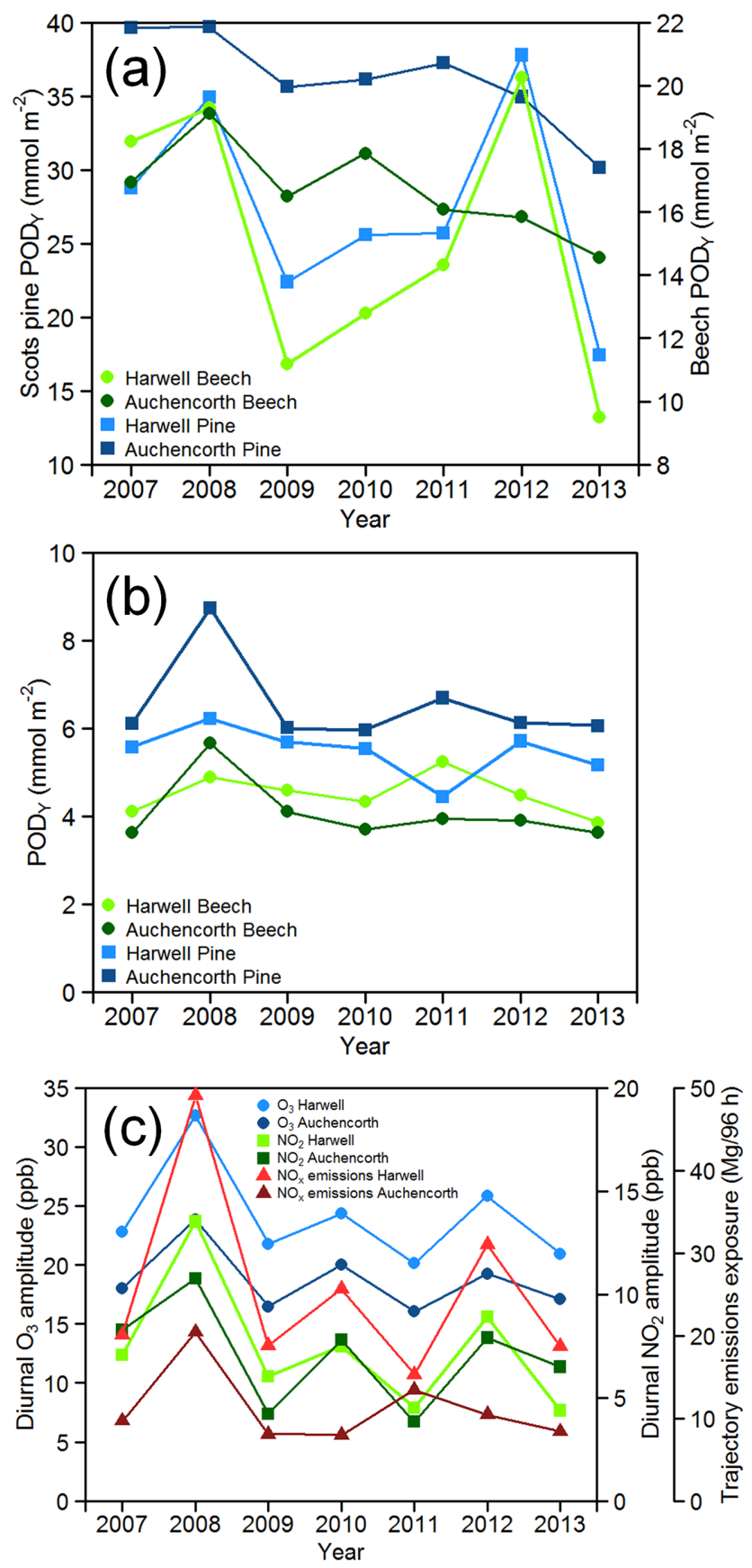

Figure 13. Comparison of $\mathrm{O}_{3}$ vegetation-impact chemical climates for beech and Scots pine 2007-2013 at Harwell and Auchencorth: (a) annual PODY for beech and Scots pine; (b) PODY accumulated in May for beech and Scots pine; (c) May monthly average diurnal amplitude of $\mathrm{O}_{3}$ and $\mathrm{NO}_{2}$ and back-trajectory $\mathrm{NO}_{x}$ emission estimates.

e.g. a $12 \%$ increase in monthly average temperature, also produced less favourable plant conditions for $\mathrm{POD}_{\mathrm{Y}}$ accumulation. 


\subsubsection{Comparison between PODY and AOT40}

The chemical climates based on the AOT40 metric (Tables S7 and S8) were derived for the crop-based AOT40 definition and are therefore most comparable with the wheat and potato $\mathrm{POD}_{\mathrm{Y}}$ chemical climates. At Harwell, there was a significant long-term decrease in AOT40 from an average of $6533 \mathrm{ppbh}$ during 1990-1993 to an average of $2623 \mathrm{ppbh}$ during 2010-2013 (trend: $-3.6 \% \mathrm{y}^{-1}, p=0.001$, Fig. 14, Table S7). This decrease in AOT40 is in contrast to the trends in wheat and potato POD $_{Y}$ at Harwell, which showed no significant trend across the 24-year period (Fig. 8a). However, the AOT40 climate showed similar decreases in diurnal pollutant amplitudes and back-trajectory $\mathrm{NO}_{x}$ emission estimates compared to the crop PODY climates, indicating increased importance of hemispheric background concentrations. This is in line with Derwent et al. (2013), who reported an increase between 1989 and 2012 in AOT40 when selecting hemispheric background air arriving at Mace Head, Ireland. AOT40 at Auchencorth was lower than at Harwell, and the magnitude of the difference was much larger than for PODY. This was similar to the spatial differences in Jenkin (2014), in which estimated regional background AOT40 was twice as large at Harwell compared to a rural site in central Scotland (EMEP site GB0033R: Bush).

The spatial difference between sites was less for $\mathrm{POD}_{\mathrm{Y}}$ because AOT40 does not account for modification of stomatal conductance, especially during summer months when SWP at Harwell can be low. Hence the average contribution from July 2010-2013 to AOT40 was 35\% but for wheat PODY only $3 \%$ (Tables S5 and S7). Conversely, the contribution from July to AOT40 at Auchencorth is lower than the contribution to wheat and potato $\mathrm{POD}_{\mathrm{Y}}$ (Tables S6 and S8), indicating that $\mathrm{O}_{3}$ concentrations below the $40 \mathrm{ppb}$ threshold determine the wheat and potato PODY $_{Y}$ to a large extent during this month. The limitations of the fixed growing season in the AOT40 concept have been detailed previously (RoTAP, 2012; Coyle et al., 2003), including the observation that there can be significant impact on vegetation below the $40 \mathrm{ppb}$ threshold. For forest trees, Gauss et al. (2014) reported forest-based AOT40 across the UK from 2007 to 2012 to be between 5 and $50 \%$ lower than that calculated in 2000 . In addition, Klingberg et al. (2014) found a much smaller decline in forest-specific POD $_{Y}$ than AOT40 between 1960 and 2100 using modelled $\mathrm{O}_{3}$ and meteorological data at 14 sites across Europe.

In summary, the crop-based AOT40 trend at Harwell showed an improvement in $\mathrm{O}_{3}$ crop impact which is not shown when the interaction between plant and $\mathrm{O}_{3}$ climates are modelled using biologically more relevant $\mathrm{POD}_{\mathrm{Y}}$ metric.

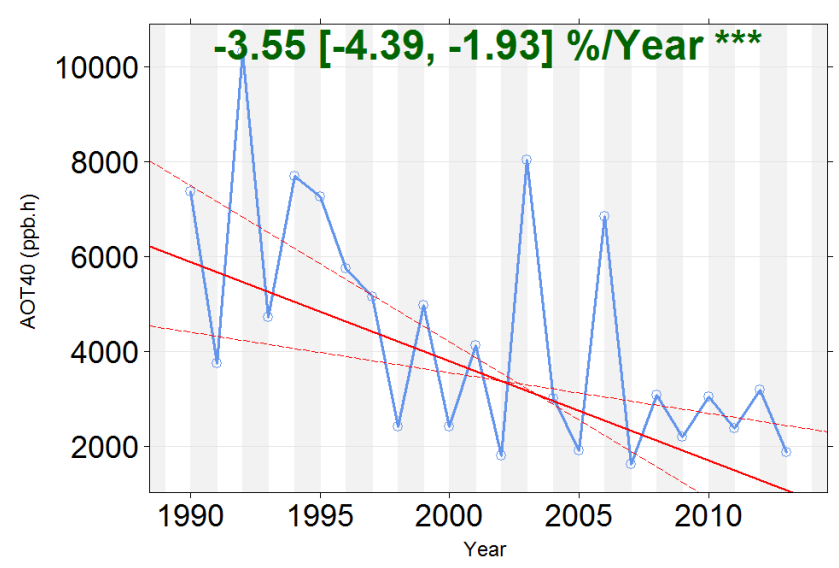

Figure 14. Crop-relevant AOT40 (calculated between May and July) at Harwell for the period 1990-2013. The Theil-Sen trend estimate of median trend (shown in red) is $-3.6 \% \mathrm{y}^{-1}(p=0.001)$.

\section{Conclusions}

A chemical climatology framework was applied to characterise $\mathrm{O}_{3}$ exposure associated with human health and vegetation impacts using measured data at the Harwell and Auchencorth UK EMEP supersites. These sites have been shown to be representative of rural $\mathrm{O}_{3}$ over the wider geographic areas of south-east England and northern UK respectively.

At Harwell, each chemical climate analysis indicated a decrease over the period 1990-2013 in the relative importance of regional photochemical $\mathrm{O}_{3}$ production, associated with $\mathrm{NO}_{x}$ emission reductions, and an increase in relative importance of hemispheric background concentrations. However, trends in the human health and vegetation metrics associated with these changes were different.

As quantified by the SOMO35 metric, the human healthrelevant $\mathrm{O}_{3}$ exposure at Harwell decreased significantly over the period $1990-2013\left(-2.2 \% \mathrm{y}^{-1}\right)$, while quantification using the SOMO10 metric showed no trend due to its lower dependence on the highest $\mathrm{O}_{3}$ concentrations, which have decreased due to declining regional photochemical production. Hence the choice of these two $\mathrm{O}_{3}$ concentration thresholds, both recommended by WHO REVIHAAP for health impact assessments, determines both the perceived annual pattern of health burden and whether there has been improvement in time. The policy significance of these findings is important since the regional policies adopted to date, regarding controls on $\mathrm{NO}_{x}$ and VOC emissions in Europe, have been effective in reducing peak concentrations and exposure. The growth in these emissions elsewhere has increased the importance of background contribution to $\mathrm{O}_{3}$ exposure in the UK. The effective controls for background $\mathrm{O}_{3}$ would be controls at hemispheric scales on $\mathrm{O}_{3}$ precursors and in methane emissions especially.

The PODY metrics used to quantify the impact of $\mathrm{O}_{3}$ on vegetation showed no change over the period 1990-2013 at 
Harwell for wheat and potato crops and beech and Scots pine trees, in contrast to a decreasing trend in potential impact when quantified by the crop AOT40 metric. The contrast highlights the need to model vegetation impacts using the

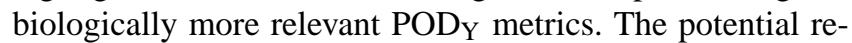
ductions in vegetation impact (i.e. POD $\mathrm{P}_{\mathrm{Y}}$ ), due to decreases in regional photochemical $\mathrm{O}_{3}$ production decreases (as reflected in the decrease in crop AOT40 at Harwell), did not occur due to the other factors that reduce plant stomatal conductance and hence accumulated $\mathrm{O}_{3}$ uptake (e.g. changing plant phenology and low soil water potential). Thus the longterm decrease in regional $\mathrm{O}_{3}$ production evident at Harwell led to a lower beneficial effect on PODY than on SOMO35.

The chemical climates indicate a greater influence of hemispheric background concentrations at Auchencorth compared to Harwell (for the period 2007-2013). SOMO10 values were similar at both sites, but SOMO35 was lower at Auchencorth. POD $\mathrm{Y}$ values were larger for vegetation species with longer growing seasons and lower thresholds for exceedance compared to Harwell (i.e. for beech and Scots pine). In addition, more favourable plant conditions (higher SWP, longer accumulated temperature-derived growing season) during periods of elevated regional $\mathrm{O}_{3}$ production resulted in exacerbation of vegetation impacts at Auchencorth compared to Harwell. Hence the potential for $\mathrm{O}_{3}$ vegetation impact reduction from future reductions in regional $\mathrm{O}_{3}$ is greater at Auchencorth than at Harwell, despite being further from the major sources of $\mathrm{O}_{3}$ precursors. However, the policies required to substantially reduce exposure of vegetation in the UK to damage from $\mathrm{O}_{3}$, like those for human health, are measures that reduce the background $\mathrm{O}_{3}$ concentrations - hence the need for hemispheric control measures on $\mathrm{O}_{3}$ precursors.

\section{The Supplement related to this article is available online at doi:10.5194/acp-15-4025-2015-supplement.}

Acknowledgements. C. S. Malley acknowledges the University of Edinburgh School of Chemistry, the NERC Centre for Ecology \& Hydrology (NERC-CEH studentship funding project no. NEC04544) and the UK Department for Environment, Food and Rural Affairs (Defra, grant no. AQ0647) for funding. Defra contractors Ricardo-AEA, Bureau Veritas and NERC Centre for Ecology \& Hydrology and their field teams are acknowledged for operating the UK EMEP Supersites. Particular acknowledgement goes to Mhairi Coyle for valuable discussion regarding AOT40 calculation and to David Fowler for insightful discussion regarding

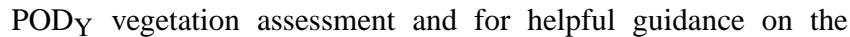
policy relevancy of this work.

Edited by: P. Monks

\section{References}

Abbatt, J., George, C., Melamed, M., Monks, P., Pandis, S., and Rudich, Y.: New Directions: Fundamentals of atmospheric chemistry: Keeping a three-legged stool balanced, Atmos. Environ., 84, 390-391, 2014.

Angus Smith, R.: Air and Rain: The Beginnings of a Chemical Climatology, Longmans, Green and Co., London, 1872.

AQEG: Ozone in the United Kingdom: Air Quality Expert Group, Defra Publications, London, available at: http://uk-air.defra.gov. uk/assets/documents/reports/aqeg/aqeg-ozone-report.pdf (last access: 19 January 2015), 2009.

Büker, P., Morrissey, T., Briolat, A., Falk, R., Simpson, D., Tuovinen, J. P., Alonso, R., Barth, S., Baumgarten, M., Grulke, N., Karlsson, P. E., King, J., Lagergren, F., Matyssek, R., Nunn, A., Ogaya, R., Peñuelas, J., Rhea, L., Schaub, M., Uddling, J., Werner, W., and Emberson, L. D.: DO3SE modelling of soil moisture to determine ozone flux to forest trees, Atmos. Chem. Phys., 12, 5537-5562, doi:10.5194/acp-12-5537-2012, 2012.

Carslaw, D. C. and Ropkins, K.: Openair: Open-source tools for the analysis of air pollution data, R package version 0.8-5, 2013.

Coyle, M., Smith, R. I., Stedman, J. R., Weston, K. J., and Fowler, D.: Quantifying the spatial distribution of surface ozone concentration in the UK, Atmos. Environ., 36, 1013-1024, 2002.

Coyle, M., Fowler, D., and Ashmore, M.: New directions: Implications of increasing tropospheric background ozone concentrations for vegetation, Atmos. Environ., 37, 153-154, 2003.

Derwent, R., Manning, A., Simmonds, P., Gerard Spain, T., and O'Doherty, S.: Analysis and interpretation of 25 years of ozone observations at the Mace Head Atmospheric Research Station on the Atlantic Ocean coast of Ireland from 1987 to 2012, Atmos. Environ., 80, 361-368, 2013.

Draxler, R. R. and Rolph, G. D.: HYSPLIT (HYbrid Single-Particle Lagrangian Integrated Trajectory) Model access via NOAA ARL READY Website, NOAA Air Resources Laboratory, available at: http://www.arl.noaa.gov/HYSPLIT.php (last access: 19 January 2015), College Park, MD., 2013.

Eaton, S. and Stacey, B.: QA/QC Data Ratification Report for the Automatic Urban and Rural Network, OctoberDecember 2011, and Annual Report 2011, AEAT/ENV/R/3284 Issue 1. Contract Report to the Department for Environment, Food and Rural Affairs, AEA, available at: http://uk-air.defra.gov.uk/assets/documents/reports/cat05/ 1207040912_AURN_2011_Q4_Issue_1.pdf (last access: 19 January 2015), 2012.

EEA: Overview of exceedances of EC ozone threshold values: April-September 2013. EEA technical report No 3/2014, European Environment Agency, available at: http://www.eea.europa. eu/publications/air-pollution-by-ozone-across-1, 2014a.

EEA: EU emission inventory report 1990-2012 under the UNECE Convention on long-range transboundary air pollution (LRTAP). EEA technical report No 12/2014, European Environment Agency, available at: http://www.eea.europa.eu/publications/ eu-emission-inventory-report-lrtap, 2014b.

Emberson, L. D., Ashmore, M. R., Cambridge, H. M., Simpson, D., and Tuovinen, J. P.: Modelling stomatal ozone flux across Europe, Environ. Pollut., 109, 403-413, 2000.

Emberson, L. D., Buker, P., and Ashmore, M. R.: Assessing the risk caused by ground level ozone to European forest trees: A case 
study in pine, beech and oak across different climate regions, Environ. Pollut., 147, 454-466, 2007.

EMEP: Transboundary particulate matter, photo-oxidants, acidifying and eutrophying components. EMEP Status Report 1/2014. European Monitoring and Evaluation Programme, available at: http://emep.int/publ/reports/2014/EMEP_Status_ Report_1_2014.pdf (last access: 19 January 2015), 2014.

Fuhrer, J., Skarby, L., and Ashmore, M. R.: Critical levels for ozone effects on vegetation in Europe, Environ. Pollut., 97, 91-106, 1997.

Gauss, M., Semeena, V., Benedictow, A., and Klein, H.: Transboundary air pollution by main pollutants ( $\mathrm{S}, \mathrm{N}$, Ozone) and PM: The United Kingdom. MSC-W Data Note 1/2014, available at: http://www.emep.int/publ/reports/2012/Country_ Reports/report_GB.pdf (last access: 19 January 2015), 2014.

Guerreiro, C. B. B., Foltescu, V., and de Leeuw, F.: Air quality status and trends in Europe, Atmos. Environ., 98, 376-384, 2014.

Heal, M. R., Heaviside, C., Doherty, R. M., Vieno, M., Stevenson, D. S., and Vardoulakis, S.: Health burdens of surface ozone in the UK for a range of future scenarios, Environ. Int., 61, 36-44, 2013.

Jenkin, M.: Trends in ozone concentration distributions in the UK since 1990: Local, regional and global influences, Atmos. Environ., 42, 5434-5445, 2008.

Jenkin, M.: Investigation of an oxidant-based methodology for AOT40 exposure assessment in the UK, Atmos. Environ., 94, 332-340, 2014.

Karlsson, P. E., Tang, L., Sundberg, J., Chen, D., Lindskog, A., and Pleijel, H.: Increasing risk for negative ozone impacts on vegetation in northern Sweden, Environ. Pollut., 150, 96-106, 2007.

Kaufman, L. and Rousseeuw, P. J.: Finding Groups in Data: An Introduction to ClusterAnalysis, Wiley, New York, Wiley, New York, 1990.

Klingberg, J., Engardt, M., Uddling, J., Karlsson, P. E., and Pleijel, H.: Ozone risk for vegetation in the future climate of Europe based on stomatal ozone uptake calculations, Tellus A, 63, 174$187,2011$.

Klingberg, J., Engardt, M., Karlsson, P. E., Langner, J., and Pleijel, H.: Declining ozone exposure of European vegetation under climate change and reduced precursor emissions, Biogeosciences, 11, 5269-5283, doi:10.5194/bg-11-5269-2014, 2014.

Kuhlbusch, T., Quincey, P., Fuller, G., Kelly, F., Mudway, I., Viana, M., Querol, X., Alastuey, A., Katsouyanni, K., Weijers, E., Borowiak, A., Gehrig, R., Hueglin, C., Bruckmann, P., Favez, O., Sciare, J., Hoffmann, B., EspenYttri, K., Tørseth, K., Sager, U., Asbach, C., and Quass, U.: New Directions: The future of European urban air quality monitoring, Atmos. Environ., 87, 258260,2014

Lee, J. D., Lewis, A. C., Monks, P. S., Jacob, M., Hamilton, J. F., Hopkins, J. R., Watson, N. M., Saxton, J. E., Ennis, C., Carpenter, L. J., Carslaw, N., Fleming, Z., Bandy, B. J., Oram, D. E., Penkett, S. A., Slemr, J., Norton, E., Rickard, A. R., Whalley, L. K., Heard, D. E., Bloss, W. J., Gravestock, T., Smith, S. C., Stanton, J., Pilling, M. J., and Jenkin, M. E.: Ozone photochemistry and elevated isoprene during the UK heatwave of August 2003, Atmos. Environ., 40, 7598-7613, 2006.

LRTAP Convention: Chapter 3 of the LRTAP Convention Manual of Methodologies for Modelling and Mapping Effects of Air Pollution, edited by: Mills, G., Pleijel, H., Büker, P., Braun, S., Ember- son, L., Harmens, H., Simpson, D., Grünhage, L., Karlsson, P., Danielsson, H., Bermejo, V., and Gonzalez-Fernandez, I., available at: http://icpvegetation.ceh.ac.uk/ (last access: 19 January 2015), 2010.

Malley, C. S., Braban, C. F., and Heal, M. R.: The application of hierarchical cluster analysis and non-negative matrix factorization to European atmospheric monitoring site classification., Atmos. Res., 138, 30-40, 2014a.

Malley, C. S., Braban, C. F., and Heal, M. R.: New Directions: Chemical climatology and assessment of atmospheric composition impacts, Atmos. Environ., 87, 261-264, 2014b.

Mangiameli, P., Chen, S. K., and West, D.: A comparison of SOM neural network and hierarchical clustering methods, Eur. J. Oper. Res., 93, 402-417, 1996.

Mareckova, K., Wankmueller, R., Whiting, R., and Pinterits, M.: Review of emission data reported under the LRTAP Convention and NEC Directive, Stage 1 and 2 review, Review of emission inventories from shipping, Status of Gridded and LPS data, EEA and CEIP technical report, 1/2013, ISBN 978-3-99004248-9, available at: http://www.ceip.at/review-of-inventories/ review-2013/ (last access: 19 January 2015), 2013.

Mills, G., Hayes, F., Norris, D., Hall, J., Coyle, M., Cambridge, H., Cinderby, S., Abbott, J., Cooke, S., and Murrells, T.: Impacts of Ozone Pollution on Food Security in the UK: a Case Study for Two Contrasting Years, 2006 and 2008, Defra contract AQ0816, London, 2011a.

Mills, G., Hayes, F., Simpson, D., Emberson, L., Norris, D., Harmens, H., and Büker, P.: Evidence of widespread effects of ozone on crops and (semi-)natural vegetation in Europe (1990-2006) in relation to AOT40-and flux-based risk maps, Global. Change. Biol., 17, 592-613, 2011b.

Mills, G., Pleijel, H., Braun, S., Bueker, P., Bermejo, V., Calvo, E., Danielsson, H., Emberson, L., Gonzalez Fernandez, I., Gruenhage, L., Harmens, H., Hayes, F., Karlsson, P.-E., and Simpson, D.: New stomatal flux-based critical levels for ozone effects on vegetation, Atmos. Environ., 45, 5064-5068, 2011c.

Munir, S., Chen, H., and Ropkins, K.: Quantifying temporal trends in ground level ozone concentration in the UK, Sci. Total Environ., 458, 217-227, 2013.

Parrish, D. D., Law, K. S., Staehelin, J., Derwent, R., Cooper, O. R., Tanimoto, H., Volz-Thomas, A., Gilge, S., Scheel, H. E., Steinbacher, M., and Chan, E.: Lower tropospheric ozone at northern midlatitudes: Changing seasonal cycle, Geophys. Res. Lett., 40, 1631-1636, 2013.

R Core Development Team: R: A language and environment for statistical computing, R Foundation for Statistical Computing, Vienna, Austria, ISBN 3-900051-07-0, available at: http://www. R-project.org. (last access: 19 January 2015), 2008.

REVIHAAP: Review of evidence on health aspects of air pollution - REVIHAAP Project technical report. World Health Organization (WHO) Regional Office for Europe, Bonn, available at: http://www.euro.who.int/_data/assets/pdf_file/0004/193108/ REVIHAAP-Final-technical-report-final-version.pdf (last access: 19 January 2015), 2013

RoTAP: Review of Transboundary Air pollution: Acidification, Eutrophication, Ground Level Ozone and Heavy metals in the UK, Contract Report to the Department for Environment, Food and Rural Affairs, Centre for Ecology and Hydrol- 
ogy, available at: http://www.rotap.ceh.ac.uk/sites/rotap.ceh.ac. uk/files/CEHRoTAP.pdf (last access: 19 January 2015), 2012.

Schmale, J., van Aardenne, J., and von Schneidemesser, E.: New Directions: Support for integrated decision-making in air and climate policies - Development of a metrics-based information portal, Atmos. Environ., 90, 146-148, 2014.

Simpson, D., Ashmore, M. R., Emberson, L., and Tuovinen, J. P.: A comparison of two different approaches for mapping potential ozone damage to vegetation. A model study, Environ. Pollut., 146, 715-725, 2007.

Simpson, D., Benedictow, A., Berge, H., Bergström, R., Emberson, L. D., Fagerli, H., Flechard, C. R., Hayman, G. D., Gauss, M., Jonson, J. E., Jenkin, M. E., Nyíri, A., Richter, C., Semeena, V. S., Tsyro, S., Tuovinen, J. P., Valdebenito, Á., and Wind, P.: The EMEP MSC-W chemical transport model - technical description, Atmos. Chem. Phys., 12, 7825-7865, doi:10.5194/acp-127825-2012, 2012.

Stedman, J. R. and Kent, A. J.: An analysis of the spatial patterns of human health related surface ozone metrics across the UK in 1995, 2003 and 2005, Atmos. Environ., 42, 1702-1716, 2008.

Tørseth, K., Aas, W., Breivik, K., Fjæraa, A. M., Fiebig, M., Hjellbrekke, A. G., Lund Myhre, C., Solberg, S., and Yttri, K. E.: Introduction to the European Monitoring and Evaluation Programme (EMEP) and observed atmospheric composition change during 1972-2009, Atmos. Chem. Phys., 12, 5447-5481, doi:10.5194/acp-12-5447-2012, 2012.
UK Meteorological Office: Met Office Integrated Data Archive System (MIDAS) Land and Marine Surface Stations Data (1853-current), (Internet), NCAS British Atmospheric Data Centre, 2014, available at: http://catalogue.ceda.ac.uk/uuid/ 220a65615218d5c9cc9e4785a3234bd0 (last access: 19 January 2015), 2012.

Vieno, M., Dore, A. J., Stevenson, D. S., Doherty, R., Heal, M. R., Reis, S., Hallsworth, S., Tarrason, L., Wind, P., Fowler, D., Simpson, D., and Sutton, M. A.: Modelling surface ozone during the 2003 heat-wave in the UK, Atmos. Chem. Phys., 10, 7963-7978, doi:10.5194/acp-10-7963-2010, 2010.

WHO: Air Quality Guidelines. Global update 2005. Particulate matter, ozone, nitrogen dioxide and sulfur dioxide., World Health Organisation Regional Office for Europe, Copenhagen, ISBN 92 8902192 6, available at: http://www.euro.who.int/_data/assets/ pdf_file/0005/78638/E90038.pdf (last access: 19 January 2015), 2006.

Wilson, R. C., Fleming, Z. L., Monks, P. S., Clain, G., Henne, S., Konovalov, I. B., Szopa, S., and Menut, L.: Have primary emission reduction measures reduced ozone across Europe? An analysis of European rural background ozone trends 1996-2005, Atmos. Chem. Phys., 12, 437-454, doi:10.5194/acp-12-437-2012, 2012. 